\title{
Anthropology of extremality: social and cultural everyday adaptation of the ethnic deportees (the years 1939-1949) and host rural community in the South of Western Siberia in the context of involuntary deportations
}

DOI: 10.31551/2410-2725-2019-5-2-197-231

\section{Shcheglova Tatiana Kirillovna}

Doctor of Historical Sciences, Head of the Department of National history of the Faculty of History of Altai State Pedagogical University, Barnaul, Russia. E-mail: tk_altai@mail.ru

Abstract. The subject of research is the historical memory about ethnic deportations of the years 1939-1949 to the territory of the South of Western Siberia. The main sources are expedition materials of oral history, ethnography and social anthropology for the years 1990-2010. Innovativeness of the approach is realized through the accentuation on the issues of interaction of two groups of participants - host community and settled ethnic deportees (Ukrainians, Belarusians, Lithuanians, Poles, Germans, Kalmyks, Armenians, Chechens etc.), social, economical, cultural and civil adaptations of both groups. The author makes the conclusion that disperse disposal of the deportee mostly in Russian speaking community and family character of deportations led to polyethnicity of rural settlements having created on everyday level the unique situation of interaction and mutual influence. The article compares the processes of disposal of ethnic deportees, the influence on their everyday practices of economical and cultural traditions and way of, historical events, state policy, mythologemas and stereotypes. The reasons of tension as well as the methods and ways of its overcoming are analyzed. The conclusion is made that after overcoming mutual offences and accusations on the everyday level, due to economical and cultural interchange in everyday interaction the unitary system of overcoming difficulties in the struggle with cold and hunger was formed with the infusion of nonethnic elements into traditional cultural standards of the participants. The value of ethnic deportees for development of host agricultural production and rural community is defined. The innovative conclusion made by the author consists in the fact that everyday adaptation practices were influenced by the multiple identity of the deportees that marked not only the borderline between agricultural and stock-raising, steppe and mountain ethnical groups, but also the borderline of the deportees' origin - a village or a city, peasantry or intelligentsia, the West or the East.

Keywords:ethnic deportees, historical memory, ethnic deportees, Russian Siberians, conditions of placements, social and cultural everyday adaptation, interaction and mutual influence

\section{Экстремалдық антропологиясы: күштеп қоныс аудару контексіндегі этникалық депортанттардың (1939-1949 жж.) және оларды Батыс Сібірдің оңтүстігіне қабылдаған ауыл қоғамының әлеуметтік және мәдени- тұрмыстық бейімделуі}

\section{Щеглова Татьяна Кирилловна}

тарих ғылымының докторы, Алтай мемлекеттік педагогикалық университеті тарих факультетінің отан тарихы кафедрасының меңгерушісі, Барнаул, Ресей Федерациясы. E-mail: tk altai@mail.ru Аңдатпа. Зерттеу пәні 1939-1949 жылдар аралығында Батыс Сібірдің оңтүстігі аумағына
этникалық күштеп қоныс аударылғандар туралы тарихи жады болып табылады. 1990-2010
жылдардағы ауызша тарих, этнография және әлеуметтік антропологияның экспедициялық
материалдары негізгі дерек көздері ретінде есептеледі. Бұл көзқарастың жаңашылдығы -
жергілікті халық пен депортацияланған этностардың (украиндар, белорустар, литвалықтар,
поляктар, немістер, калмақтар, армяндар, шешендер және т.б.) өзара қатынасы мәселесіне
ерекше назар аудара отырып, олардың әлеуметтік, шаруашылықтық - мәдени және екі топтың
да азаматтық бейімделуін зерттеуге назар аударылған. Автор орыс тұрғындары басым ортаға
депортацияланғандарды орналастыруы және депортацияның отбасылық сипаты күнделікті
деңгейде бірегей өзара байланысты және өзара қатынасты жағдайды қалыптастырғандығы
туралы қорытынды жасайды. Мақалада этникалық депортанттарды қамау үрдісі, тарихи
оқиғалардың, мемлекеттік саясаттың олардың шаруашылықтық - мәдени дәстүрлері мен өмір
салтындағы күнделікті тәжірибесіне тигізген әсеріне салыстырмалы талдау жасалады. Сонымен
қатар, шиеленістің себептері, оны жеңудің тәсілдері мен жолдары талданады. Тұрмыстық
деңгейде өзара реніш пен наразылықтарды жеңгеннен кейін, күнделікті қарым-қатынаста
шаруашылық-мәдени өзара алмасудың арқасында және олардың дәстүрлі мәдени
стандарттарына бөгде этностық элементтердің енуімен суық пен аштыққа қарсы күресте 
қиындықтарды еңсерудің бірыңғай жүйесі қалыптасты деген қорытынды жасалады. Жергілікті ауыл шаруашылығы өндірісін және ауыл қоғамын дамыту үшін этникалық депортанттардың маңызы айқындалады. Депортанттардың көптеген бірегейлік бейімделушілік күнделікті тәжірибесіне тек егіншілікті немесе мал шаруашылықты, далалық немесе таулы халықтардың шекарасы арқылы ғана емес, сонымен қатар, ауыл мен қала, шаруа мен зиялы қауым, батыс пен шығыс бірегейлігі бойынша болғандығын дәлелдей мақаланың жаңашыл көзқараста екендігін көрсетеді.

Түйінді сөздер: депортациялар, тарихи жады, этникалық депортанттар, орыс сібірліктер, қамау жағдайы, әлеуметтік және мәдени - тұрмыстық бейімделу, өзара әрекет, өзара байланыс.

\section{Антропология экстремальности: социальная и культурно-бытовая адаптация этнических депортантов (1939-1949 годы) и принимающего сельского общества на юге Западной Сибири в контексте принудительных переселений}

\section{Щеглова Татьяна Кирилловна}

доктор исторических наук, зав. кафедрой отечественной истории исторического факультета Алтайского государственного педагогического университета. Барнаул, Россия. E-mail: tk_altai@mail.ru

Аннотация. Предметом исследования является историческая память об этнических депортациях с 1939 до 1949 годов на территорию юга Западной Сибири. Основными источниками являются экспедиционные материалы устной истории, этнографии и социальной антропологии за 1990-2010-е годы. Новационность подхода реализуется через акцентуацию на вопросах взаимоотношения двух групп участников - местного населения и водворенных этнических депортантов (украинцы, белорусы, литовцы, поляки, немцы, калмыки, армяне, чеченцы и др.), социальной, хозяйственно-культурной и гражданской адаптации тех и других. Автором делается вывод, что дисперсное размещение депортируемых в среде преимущественно русского населения и семейный характер депортаций, привели к полиэтничности сельских поселений, создав на повседневном уровне уникальную ситуацию взаимодействия и взаимовлияния. В статье сравниваются процессы водворения этнических депортантов, влияние на их повседневные практики хозяйственно-культурных традиций и образа жизни, исторических событий, государственной политики, мифологем и стереотипов. Анализируются причины напряженности, способы и пути ее преодоления. Делается вывод, что после преодоления взаимных обид и претензий на бытовом уровне, благодаря хозяйственно-культурному взаимообмену в повседневном общении сформировалась единая система преодоления трудностей по борьбе с холодом и голодом с проникновением иноэтнических элементов в традиционные культурные стандарты участников. Определяется значение этнических депортантов для развития местного сельскохозяйственного производства и сельского общества. Новационным является вывод о влиянии на адаптационные повседневные практики множественной идентичности депортантов, которая проходила не только по границе земледельческих или скотоводческих, степных или горных народов, но и по границе исхода депортантов - село или город, крестьянство или интеллигенция, запад или восток.

Ключевые слова: депортации, историческая память, этнические депортанты, русские сибиряки, условия водворения, социальная и культурно-бытовая адаптация, взаимодействие, взаимовлияние.

Удк/UDC 39(571.1)+572.9

Антропология экстремальности: социальная и культурно-бытовая адаптация этнических депортантов (1939-1949 годы) и принимающего сельского общества на юге Западной Сибири в контексте принудительных переселений

\section{Т.К. Щеглова}

Введение. Исторические события XX в. обусловили активное взаимодействие народов в ходе миграций, которые по своему характеру можно 
разбить на вольно-добровольные, вынужденные и принудительнонасильственные. Уровень межэтнического согласия или напряжения в XX веке в сельском обществе Северной и Центральной Азии определялись рядом факторов. Самостоятельное влияние на развитие сельского общества в советский период сыграли принудительные депортации 1939-1949 гг., которые представляли собой опыт насильственного смешения народов, усугубленный репрессивной политикой государства в отношении людей разной этнической принадлежности, объявленных потенциальными «врагами» или «предателями» и принудительно выселенными с этнической территории. Они привели к увеличению населения края за счет этнических ссыльных. Только с 11 по 30 сентября 1941 г. на Алтай прибыло на 14 станций 34 эшелона с депортированными немцами в количестве 80454 чел., которые были расселены по 47 районам. Общая численность депортированных в регион немцев составила до 115000 чел. (Сыщенко, 2007: 6). В 1943-1944 гг. на Алтае расселили 20858 калмыков (из 91919 чел.). В составе принудительных выселений как «потенциальные пособники фашизма» на Алтае оказались поволжские и ростовские немцы, крымские татары, чеченцы, калмыки и ингуши, карачаевцы; как «представители» государств, воевавших против СССР, - этнические болгары, венгры, румыны, финны и др. Дисперсное расселение депортантов привело к тому, что за предельно короткий промежуток времени территория Алтая стала районом этнически пестрого заселения. Об этом свидетельствуют очевидцы: «Тут полно было всяких наций. И калмыки, и немцы. Всякие нации были. А потом все по своим местам уехали, когда освободили их» (АЦУиЭ ЛИК АлтГПУ, Кузовлева О.Е., 1919 г.р.): «Здесь были и немцы. И до сих пор они есть. Прям уж и в нашей родне немцы появились. И татары. И вот даже кореец есть, и украинцы. Да кого только не было!? Ведь вот в сталинские времена... Чеченцы, они тоже выселялись здесь. Чечены, армяне, калмыки...» (АЦУиЭ ЛИК АлтГПУ, Епихин И.П., 1927 г.р.)

Факторы смешения разных этнических, конфессиональных, социальных групп и историческая память современного населения создают для исследователей благоприятную среду в изучении этничности, идентичности, характера этнических процессов через изучение эмпирического опыта памяти, через сформировавшиеся образы и представления, через результаты прошлого межкультурного и межэтнического обмена. Важным является тот фракт, что в отличие от репрессий 1930-х гг. с их закрытой системой лагерей, депортантов расселяли в среде местного населения. Историческая память об этих событиях хранится не только депортантами, в большинстве своем покинувшими Алтай, но и сибирским сельским населением - участниками совместного проживания. В отличие от депортантов, это сельское население в силу разных причин не оставило воспоминаний о том, как это было в принимающем сельском обществе. Между тем депортации смоделировали взаимодействие народов в границах одного сельского социума. История Сибири, Казахстана и Центральной Азии, территории которых стали местами водворения этнических депортантов, не может быть полной без «голосов» самых массовых участников, с одной стороны, группы депортированного населения, с другой стороны, в равной степени, без изучения того сельского общества, в которое вливались принудительные переселенцы в 1939-1949 гг.

Хронология исследования обусловлена началом массовых этнических депортаций на территорию Алтая и до указа о реабилитации, положившего начало массового возвращения насильственно-принудительных мигрантов в 
родные места. В период 1939-1956 годов выделяются два этапа. Собственно, первый этап составляли годы депортаций. Для Алтая - это 10 лет, от первой депортационной волны этнических переселенцев 1939 - 1941-х гг. с западных территорий Украины, Белоруссии и территории Прибалтики, до депортационной компании 1949 г. по переселению армян и молдаван (вторая волна послевоенной депортации молдаван в соответствии с постановлением Совета Министров республики от 28 июня 1949 г. «О выселении из Молдавской ССР семей кулаков, бывших помещиков и крупных торговцев». На Алтае расселено 4262 человека. Всего в Западную Сибирь до 80\% от первой волны в 34954 человека). Второй этап включают послевоенные годы до указа о реабилитации 1956 г., после которого основная масса репрессированных депортантов вернулась на территории прежнего проживания, кроме немцев, которым запрещено было возвращаться, тем более, что Поволжская немецкая республика не была восстановлена. В постсоветских исследованиях на территории России и в других республиках основное внимание уделено вопросам собственно формирования нормативной базы и процессу депортации. Гораздо меньше уделялось внимания процессам водворения депортантов, совсем выпали из исследовательского поля вопросы совместного проживания водворенных и местных жителей в контексте истории развития принимающих территорий, а также антропологические аспекты взаимодействия и взаимовлияния «непрошенных» гостей» и «вынужденных хозяев и адаптации тех и других к обстоятельствам военного и послевоенного времени в контексте репрессивной политики государства в отношении и тех, и других.

Источниковая база. В данной публикации автором используется архив устных исторических источников, создаваемый В ходе историкоэтнографических экспедиций с 1990 года с помощью методов устной истории интервьюирования участников и очевидцев депортации народов и источников полевой этнографии и социальной антропологии (Щеглова, 2011; Щеглова, 2015) в ходе реализации авторских программ: с 1992 г. «Депортации народов и репрессии на Алтае», с 1996 г. - «Народы Алтая: история и культура», с 2014 г. - «Культура жизнеобеспечения русского сельского населения в годы Великой Отечественной: традиции и новации», с 2017 г. «Депортации на Алтай (1939-1949 гг.): хозяйственно-бытовая и социальная адаптация сельского населения («непрошенных гостей» и «вынужденных хозяев»)».

Корпус документированных интервью архива Центра устной истории и этнографии по этой проблеме содержит оценки двух групп - этнических депортантов, расселяемых в селах, и жителей сибирской деревни, принимавших депортантов. Их задокументированный жизненный опыт показал, насколько сложно, а порой и драматично складывались отношения местных и пришлых, какую они прошли эволюцию и какие фракторы влияли. Обращение к исторической памяти участников и очевидцев принудительных переселений позволяет, прежде всего, выявить особенности взаимоотношений депортированного и местного населения с обеих сторон. Особую ценность устным историческим источникам придает важное для понимания исторического прошлого восприятие происходящего в ракурсе антитезы «свои» - «чужие» и установление диалога при антитезе «мы» и «они», в условиях, когда депортанты (немцы, украинцы, болгары, гагаузы, молдаване, греки, калмыки, армяне, литовцы, евреи, поляки, татары, чеченцы, ингуши, армяне и другие) оказывались в одном населенном пункте с преимущественно русским населением. Вот как усложнение этнического состава сельского общества 
отражается на примере с. Красный Партизан Чарышского района: «в войну немцев к нам привезли, на телегах, немного, семей пять с ребятишками. В соседнее село побольше... Жили они в домах с местными. А еще калмыки были. Тех побольше было... Даже молдаване какие-то приезжали, тоже в войну. Но их не помню. Да гагаузы какие-то. А еще поляки были. Но мало. Да литовцы... Не помню их сильно...» (АЦУиЭ ЛИК АлтГПУ, Ковалик И. Н., 1927 г.р.). Этническая идентичность мигрантов в период заселения способствовало восприятию переселенцев в ракурсе «свои» и «чужие» и позволяет выявлять происходящие под воздействием этого обстоятельства изменения в сельском обществе.

В исторической науке до сих пор не преодолен отрыв изучения истории депортаций от сельской истории. Исследователи рассматривают историю насильственных переселений изолированно от социальной, культурной и производственной жизни принимающей деревни. За последние десятилетия были исследованы процессы эвакуации и депортации, а также практики размещения депортантов в местах расселения. При этом вне зоны внимания остаются вопросы адаптации самих депортантов на новом месте и адаптация местного населения к новой ситуации; влияние депортаций на сельское общество и, наоборот, влияние местного населения на мигрантов. При акцентуации внимания на данных проблемах не доставало источников о тех внутренних процессах, которые происходили в сельском, преимущественно русском сообществе, при подселении не только людей иной этнической принадлежности, но и с репутацией потенциальных «врагов народа».

Важной, упущенной в исследованиях, проблемой для современных историков является изучение процессов формирования повседневных практик преодоления трудностей в 1940-х годах с опорой на этнические традиции местного и депортируемого населения. И тех, и других объединяли голодные и холодные годы, в которые и деревенским хозяевам, и насильно переселенным этническим депортантам приходилось выживать сообща. Равное значение в жизнедеятельности и тех, и других имели адаптационные практики как в материальной сфрере - системе жизнеобеспечения (жилище, пища, одежда) семьи, так и в социальной сфере - преодоление эмоционального негатива как со стороны местного, так и депортируемого сообщества.

Условия и факторы развития сельского общества в период депортаций. Изучение антропологического содержания принудительных депортаций сопряжено с полиэтничностью, поликультурностью, поликонфессиональностью взаимодействия и взаимовлияния участников этих процессов. Успех консолидации и интеграции депортируемого и принимающего общества и их адаптационных практик был обусловлен несколькими факторами, которые условно можно разбить на внутренние (субъективные) факторы, обусловленные этнической историей и этнокультурным опытом и внешние объективные (не зависящие от этноса) условия и факторы, обусловленные историческими событиями, в контексте которых проходила жизнь социумов, в т.ч. под влиянием государственной политики.

К первым внутренним (субъективным) фракторам адаптаций относятся хозяйственно-культурные традиции этнических депортантов и принимающего этноса, которые влияли на адаптационные практики в экстремальных или затруднительных условиях. Принудительная для депортируемых смена «кормящего ландшафта» и традиционного образа жизни в отдельных случаях вела к невозможности воспроизводить в местах водворения повседневные практики жизнеобеспечения семьи всем необходимым; сопровождалась 
культурно-бытовым шоком. Ярким примером является эмпирический опыт калмыков, как скотоводов, оторванных от обжитой степи с развитым скотоводством и расселенных в лесостепных, таежных и горных территориях юга Западной Сибири среди земледельческого населения. Их системы жизнеобеспечения были основаны на скотоводческих традициях и, вырванные из привычного образа жизни, калмыки оказывались беспомощными в иной среде. Этот фрактор служил сохранению «инакости» депортантов в местах расселения, консолидации по этническому принципу, то что респонденты часто называют жили «кучками» - «жались кучками друг к другу». В этом смысле более «комфортные» условия хозяйственно-бытовой (не социальной) адаптации по сравнению с калмыками имели депортированные из Поволжья немцы, повседневная система жизнеобеспечения которых, базировалась на семейных земледельческих и огороднических практиках, таких же, как и у принимающего, преимущественно, русского населения. И, наоборот, более неблагоприятные условия, чем у калмыков, были для социальной адаптации немцев в условиях войны с фрашисткой Германией, которая в «народных представлениях» под влиянием пропаганды ассоциировалась с «немецкостью».

Иные фракторы влияли на адаптацию к новым общественно-бытовым условиям территории размещения депортированных тех принудительных переселенцев, чья повседневная культура сорормировалась в контексте процессов глобализации и урбанизации западноевропейской цивилизации. Можно говорить, что культурно-бытовые традиции депортантов 1939 года (по пакту Молотова - Риббентропа) с территорий западной Украины, западной Белоруссии и Прибалтики, а это депортированные на Алтай украинцы, поляки, белорусы, литовцы, эстонцы, ментально, духовно и материально тяготели к «западности». Проявлялось это в том числе (условия переселения предвоенных депортантов, отличались от «военных» депортантов) в привозе предметов, маркирующих городскую культуру, менее этнически окрашенную, более универсальную (например, фабричный текстиль вместо своедельной ткани). Вот как это проявляется в материалах интервью респондента из местного населения, «Вот, да, литовцы были [село Карагуж, Красногорский район]... Я даже литовца учила. Двух даже. Витекайте...А вторую... забыла фамилию... они привозили кое-что. Вот, барахло... Привозили платья [фабричная одежда и ткань]. Материал какой [в селе преобладала своедельная ткань]» (АЦУиЭ ЛИК АлтГПУ, Шемонаева 3. С., 1925 г.р.). Описываемое респондентами повседневное поведение депортантов с западных территорий демонстрирует значительную степень трансформации традиционных культур ее носителей, в т.ч. благодаря взаимовлиянию «западноевропейских» культур. Особенно это проявлялось в повседневной культуре под влиянием происходящих в Европе процессов модернизации культурно-бытовой жизни, что было особенно заметно в сравнении с сельскими сибиряками.

Полевые исследования показали, что грань между приносившими «иную» культуру («инакость») депотрантами и местным принимающим населением пролегала глубже, чем это кажется на первый взгляд, и была связана с более широким понятием «идентичности». Под идентичностью понимается не только этничность. Идентичность включала и другие виды самоидентификации, например, «сельскую» (сельскость) и «городскую» культуру, «западность» и «восточность» (Западная Европа и Восточная Европа») и т.д. Так в исторической памяти сибирских старожилов представления о поляках прочно 
связались с такими новациями для сельского населения, как «невиданные музыкальные инструменты», «оркестры», «туфли»; о литовцах - с нетрадиционным для русского сельского населения мужским костюмным комплектом - жилет, брюки, белые рубашки. Вот как описывают поляков и греков: «помню, что они очень были религиозные. Поляки особенно... нас просили, детей, ходить славить... в праздники, в Пасху, в Рождество. Шли колядовали. они нас учили каким то там словам, я теперь не помню. Поляки всегда угощали очень вкусными конфетами... Греков я помню, они [...], особенно женщины, уже в то время были нарядными... Господи, кто ходил в лодочках лакированных, а они в лодочках лакированных, а мы, дети, бегали смотрели на эти лодочки, а потом ходили вот так, имитируя эти лодочки». (АЦУиЭ ЛИК АлтГПУ, Быкова Р.К., 1941 г. р.).

Другим важным фактором взаимоотношений вынужденных переселенцев и принимающего общества являлся разный материально-технический уровень развития территорий в стране. Прежде всего, необходимо учитывать отставание сибирских территорий в модернизации деревенской повседневной и производственной базы. Особенно это заметно было в электрофикации сельской местности, в жилищном и производственном секторе сибирской деревни. Например, материалы интервью показывают существенную разницу в соцкультбыте между селами Алтая и Поволжской республики немцев. Вот как показывают эту разницу респонденты из депортированных немцев и респонденты из местного русского населения. Первая цитата (девочка из депортированных немцев): «Когда началась война, нас стали переселять сюда, мы считаемся репрессированные. Мне было в то время шесть лет... Там [в Поволжье] было большое село, электричество было, люди там лучше жили, чем здесь, в Сибири. Мама стряпала хлеб для колхоза, а отец работал бригадиром на животноводстве... Куда везут, никто не знал... Приехали... Нас расселили по семьям, там темнота была [в семье, куда подселили депортированную семью]. У нас-то [Поволжье] уже электричество было. У них «коптюшечки» были. Мама сидит, плачет, бабушка плачет, нас стали угощать капустой, картошкой в мундире. У них мы жили лет пять.» (Алтайская деревня, 2012: 147-148). Вторая цитата (респондент из сельской семьи Горного Чарыша)«Мы часто сидели вечерами, учили уроки у печи. Разжигали лучины и с таким огоньком готовились к урокам... Эрик [одноклассник из депортированных немцев] это увидел и стал приходить к нам с керосиновой лампой» (Алтайская деревня, 2012: 69).Пытаясь понять причины разницы, респондент обобщает «культурнее нас были, что-ли» (Алтайская деревня, 2012: 69).Примерно этот же смысл содержит и оценка со стороны депортированных немцев: «То ли отстающий народ тут был. Я не знаю. У нас уже культура лучше была, намного лучше была, чем тут народ был. И победнее жили, чем мы там» (АЦУиЭ ЛИК АлтГПУ, Йорк М. Е., 1923 г.р.). На самом деле здесь речь должна идти не о культуре, как ее определяют этнографы, а о более развитой в селах Поволжской немецкой республики производственной и соцкультбытовой сорере. Что касается оценки «победнее», то это подтверждают многочисленные устные свидетельства и той, и другой стороны. Как, например, в цитате: «Их [немцев] с Алейска сначала на лошадях, тогда транспорта никакого не было ... Вот начало зимы, почему-то мне так запомнилось это... они приезжали, некоторые даже вот с мукой... Побогаче были русских» (АЦУиЭ ЛИК АлтГПУ, Коротких Ю.К., 1932 г.р.).

Образы, стереотипы, мифологемы, идеологемы, агитпропы как факторы адаптации. В процессах переселений и смешения народов на 
микроуровне, сельского поселения, формирование образов участников являлось важным фрактором взаимоотношений на начальном этапе и в последующем, в совместном общежительстве. Содержательной частью процессов взаимодействия являлись условия и время вливания в сельское общество, степень и вклад в создание совместной системы жизнеобеспечения, общественное согласие и комфортность; степень консолидации общества. Значительное влияние оказывали представления «друг о друге» в виде образов, стереотипов, мифологем, идеологем. Важно различать образы и стереотипы, мифологемы и идеологемы. В основе образов, например, по мнению автора, лежит эмпирический жизненный опыт общения в ходе исторических событий в условиях вынужденного совместного общежительства, в т.ч. В совместной борьбе с трудностями жизнедеятельности военного времени. Стереотипы являются более сложным и длительно историческим явлением, на формирование которого влияли несколько фракторов, среди которых ведущую роль играли сформировавшиеся хозяйственно-бытовые представления земледельцев или скотоводов, охотников или рыболовов, определенное влияние оказывала государственная политика. Формирование стереотипов также тесно связано с народной мифологией, отражавшей народный опыт взаимодействия в исторический прошлом. Идеологемы формируются в контексте влияния на общественное мнение государственной политики. Близко к ним стоят агитпропы - образы пропаганды и агитации.

Как показывают материалы интервью, в восприятии этнических депортантов на первом этапе вселения и знакомства сильно влияли идеологемы и стереотипы. И лишь на втором этапе - совместной деятельности, особенно В производственной сфрере, формировались самостоятельные образы этнических депортантов. При этом в процессах взаимодействия принудительных мигрантов и местного населения в Сибири необходимо учитывать тот фрактор, что для сельского русского населения этнические миграции не являлись чем-то неожиданным и новым. Образы и представления у местного русского населения многих депортантов формировались в предшествующий период межэтнического взаимодействия в массовых крестьянских переселениях второй половины XIX - первых десятилетий ХХстолетия. Он был положительным и сыграл свою конструктивную роль в 1940-е годы.

Усиливала этот фрактор в период этнических депортаций определенная аполитичность крестьянства Сибири, которая обусловливала и особенности противостояния в предшествующие годы революций и гражданской войны (Щеглова, 2008). Основой этой аполитичности являлась сосредоточенность крестьян-земледельцев на развитии хозяйства, как основы семейной системы жизнеобеспечения. Устные свидетельства показывают, что отстраненность от большой политики, сохранялась в определенной степени и в 1920-40-е годы, в т.ч. проявляясь в интерпретациях сельчанами, особенно в женских интервью, причин появления в селах этнических депортантов. Так, объясняя появление депортированных украинцев в 1939 году в с. Карагуж, 3.Я. Шемонаева пытается опереться на семейную историческую память о переселенцах рубежа XIX -XX вв. «...ехали они добровольцы, с Украины бежали. Чтоб, э... В Сибирь же мала заселена. Мало народу и вот они по собственному желанию, предложенному государством. Вот, кто согласен приехать семьями в Сибирь. Им давали льготу. Вот, например, они в нашу деревню приехали, 9 семей, хохлов этих». (АЦУиЭ ЛИК АлтГПУ, Шемонаева 3.С., 1925 г.р.). При такой прагматичности для большинства сельского населения было неважно 
понимание «кто - они» «они - просто другие» «Были ли эстонцы или литовцы, но я совсем маленький. Знаю, что были какие-то нации, кроме немцев, но я не знаю сейчас, как их называли. По-моему литовцы». (АЦУиЭ ЛИК АлтГПУ, Рябоконев И.В., 1934 г.р.).

Особенности формирования стереотипов и образов этнических депортантов под влиянием войны. На формирование стереотипов немцев у местного населения несомненно повлияла государственная компания в СМИ. Подтверждение этому содержится многократно в той или иной форме в большинстве материалов интервью. На бытовом уровне это проявляется в использовании агитпроповских штампов, например,: ««Немцы переселялися. Четыре семьи немцев жило [с. Красногорское]. Почему переселялись? Потому что с Поволжья. Немцы подходили. А они на Поволжье жили. Их выселяли, потому что боялись, что они тоже [поддержат]. Это русские немцы. Ну они понемецки, вот Иван сейчас даже по-русски с акцентом. А он 28-го года. Сейчас даже говорит по-русски, а акцент немецкий весь. Ну, вот и выселяли их. Тогда же и Чечню расселяли, и многих тогда. А немцев на Волге оставишь что ли? Когда немцы к Волге подходили уже. Ясное выселять надо было» (АЦУиЭ ЛИК АлтГПУ, Рябоконев И.В., 1934 г.р.).

При формировании образов и стереотипов на бытовом уровне межэтнические явления могли служить преградой на пути установления общественного согласия или служить благоприятным фактором. Например, в повседневной жизни на взаимоотношения мигрантов и местного населения влиял языковый барьер. Вот как рассказывала о языковой разнице между депортированными украинцами и русскими сибиряками В.В. Королева: «говор какой то такой... Как-то, ну не чисто так по-русски. По-сибирски...» (АЦУиЭ ЛИк АлтГПУ, Королева В.В., 1931 г.р.). При расселении нескольких групп этнических депортантов в одном населенном пункте, русский язык мог выступать как язык общения. Но анализ материалов интервью показывает, что в семьях или между собой депортанты предпочитали говорить на родном языке. Но местное население осуждало только, если депортанты говорили на своих языках в общественных местах, со временем смирившись с этим. Как говорила Р.К. Быкова, «Все знали русский язык. Ну, сами между собой они говорили на своем языке, особенно вот, украинцы. Ну, украинцы - это все понимали мы друг друга. Тогда вот это неправильно было. Ну, в общем, они придут в магазин и говорят на своем языке. А русские не хотели чтобы они говорили на своем языке. Ну, в начале вроде как то [возмущались], а потом привыкли. Все говорили на своем языке. И армяне говорили на своем, и калмыки, и немцы. Вот, сейчас у меня, вот тут вот немка живет. И вон там вон немка живет. И я им говорю, а почему вы не говорите на своем языке? Они собираются и говорят на русском: «Да как то привыкли». А тогда говорили на своем. Украинцы песни пели на своем. Они же красивые украинские песни. Все эти песни потом стали русские петь» (АЦУиЭ ЛИК АлтГПУ, Быкова Р.К., 1941 г. р.).

Непонимание и появление мифологем в повседневной жизни формировала культурно-бытовая разница, иноэтнические семейные и трудовые традиции. Респонденты безошибочно и детально описывают «инакость» депортантов.В.В. Королева правильно подмечает культурнобытовые отличия депортированных с Западной Украины украинцев«Вышивки и у нас были, и у наших были с вышивками [рубахи]. Ну, у них как-то аляпистей. Таки были,красочней.Красочные были. Сибиряки, видишь, как-то они более суровый народ, более практичный, а там теплые места то были, они тампридумывали че себе» (АЦУиЭ ЛИК АлтГПУ, Королева В.В., 1931 г.р.). 
Данное народное толкование близко к научной интерпретации этнографов, которые связывают яркость красок в традиционных костюмах с более теплым климатом, а их сдержанность с более суровыми природно-климатическими условиями. Устные свидетельства показывают достаточную сохранность к 1940-м годам этнических маркеров в одежде, пище, жилище у всех этнических депортантов преимущественно из сельской местности.

Проявлялось это в том, что депортанты старались захватить то, что символизировало этническую территорию и этническую традицию. Например, материалы интервью по депортационной кампании армян 1949 года показывают, что у депортированных армян, таким этническим маркером служи их традиционный ковер. Полевые материалы повсеместно показывают устойчивость армянских традиций в экстремальных условиях - независимо от того, куда их распределяли на территории Алтая везде они появлялись с коврами, что и служило определенным маркером в складывающемся образе армян со стороны русского населения. Но сам маркер интерпретировался не как элемент традиционной культуры, как это проявляется в образе депортированных украинцев, а неверно интерпретируется как признак зажиточности и богатства по сравнению с сибиряками или другими этническими депортантами. Вот как рассуждает из степного села (Благовещенский район, село Благовещенка) респондент Т.К. Лапутина (1921 г.р.) «а армяне эти, у нас, этих сослали, они богаче были тех [сравнивает с калмыками]». И далее пытаются объяснить, исходя из сложившихся представлений о богатстве: «В верхах они [армяне] были, но у них [калмыков] не было ниче такого богатства. Армяне побогаче были. В то время, вы знаете, зайдешь, у них [армяне] такие ковры были, вот у нас [местных русских], у нас понятия не было еще о коврах об этих». Критерием богатства в представлениях русской сельчанки выступают ковры, которые для армян в повседневной жизни были не признаком зажиточности, а маркером этничности. Тогда как для русского населения появление ковров стало показателем имущественной состоятельности, что и отражается в ее оценке: «армяне богаче были, русские были нищие, они были богаче». Другим маркером армянской инакости выступила шерсть: «Теперь армяне. Вот, почему общались мы? Они приезжали, у них... матрасы. Вот такие толстые, шерстью наполненные. И, потом, они здесь их распаковывали и продавали эту шерсть....Овечья, вот. Но она отличалась от нашей... Порода не такая. Наши [овцы] шерсть сбивается, садится, а ихняя нет. И у них покупали на одеяло. Стежили одеяла с ихней шерсти»(АЦУиЭ ЛИК АлтГПУ, Лапутина Т.К., 1921 г.р.).

Таким образом, маркером этничности, как правило, выступали какие-либо выразительные элементы материальной культуры, неизвестные местному населению и присущие культуре (предметы быта, одежды, питания) прибывших депортантов. Так, у немцев таким маркером являлась обувь: ««почему то у них не было обуви. Я не могу представить. Шлеры носили. Так назывались ихняя обувь -шлеры. Это деревянная подошва. Это наподобие наших... как босоножки с этими переплетами... Они делали - деревянная подошва, из дерева и прибивали вот так вот, прямо гвоздиками прибивали. Переплеты из кожи. Мы едем, а он [мальчик] с одной стороны улицы на вторую побежал по снегу. Бежит по снегу и тут голые ноги у него и в этих, шлерах. Вот они обувались так»(АЦУиЭ ЛИК АлтГПУ, Лапутина Т.К., 1921 г.р.). В сформированном образе чеченцев местным населением также были заложены элементы традиционного костюма: ««Их выслали сюда в Кулунду... и там 
поселки... Я их иногда боялась. Высокие такие... «пурки» на них и эти «тароцы»..» Отличались чеченцы и своими трудовыми традициями. Как рассказывала этот же информант, «Берут, покупают, ну, подешевле, подороже потом продают. Каждый день. Всю войну они, наверное, здесь были, потом уехали. Ну они, как сказать, никакого вреда не делали. Они же курят. Трубки там у каждого почти. Набивают и курят. Это нигде ни папирос не было, ни табаку не было. А, вот, люди [местное сельское население] выращивали и продавали. А они потом перепродавали им курево тоже.... Это, как сказать, в крови, наверно, торговля эта была. Ходят, предлагают, вот бери ну какие вещи там. Только хто же их будет брать и за что...» (АЦУиЭ ЛИК АлтГПУ, Ярошенко М.Н., 1925 г.р.).

На формирование образов этнических мигрантов в сельской среде определенное влияние оказывали крестьянские представления, прежде всего, о хозяйственных и производственных традициях и навыках переселенных. Именно поэтому быстрее вливались в местные земледельческие коллективы русского населения этнические мигранты с похожими традициями, например, немцы. Из тех черт, которые ценились в сельском обществе и сельской семье, занятой в сельскохозяйственном труде и, которые легли в основу сложившегося положительного образа немецких депортантов, респонденты на первое место ставили их отношение к труду, который ассоциировался с земледелием. Как говорил И.А. Васютин, 1928 г. р. «Были работяги страшные. Хорошие мужики были» (АЦУиЭ ЛИК АлтГПУ,Васютин И.А., 1928 г.р.); М.Н. Ярошенко, 1925 г.р. так говорила «Они такие рукодельные были, немцы-то. А так старались они. А вообще добрые, хорошие люди, некоторые там - «О! Немец!». Ничего подобного. Я знаю, как, вот хорошие люди... Вообще они такие деловые люди. Всё у них всегда есть. Стараются все» (АЦУиЭ ЛИк АлтГПУ, Ярошенко М.Н., 1925 г.р.). Тогда как, вспоминая про калмыков, говорили больше не о «деловых», а о человеческих качествах: «хороший народ» (АЦУиЭ ЛИК АлтГПУ, Быкова Р.К., 1941 г. р.).

Контент-анализ материалов интервью показывает, что после трудолюбия на следующее место респонденты ставили понятные для них открытость, щедрость и гостеприимство. При наличии таких проявлений в поведении формировался положительный образ депортантов. Очень похожи по содержанию и тональности рассказы об армянах, «армяне, они очень трудолюбивые. Очень трудолюбивые. И они гостеприимные! Когда их сослали, они привозили с собой орехи. Сейчас помню, в мешках, грецкие орехи. И они всегда, всегда угощали. Мы дети прибежим, они обязательно угостят. Хоть три ореха, но они дадут. А нам!? Мы же не видели [орехов]. Господи! Невидаль была эта.» (АЦУиЭ ЛИК АлтГПУ, Быкова Р.К., 1941 г. р.).

Крестьянское отношение к труду и жизни определило иные образы тех этнических депортантов, которые были менее понятны своим укладом жизни и поведением. Очень в сложные ситуации были поставлены во время депортации калмыки, что наложило отпечаток на восприятие и формирование образов калмыков, про которых местное население первоначально говорило: «грязные, оборванные, голодные. Их привезли... из Барнаула или откуда... Везли на лошадях. Мы с ребятишками бегали смотрели. Ну, они ж по-своему и говорили. Как звереныши так выглядывают... Ну, конечно, они уж настолько..., они были как допотопного периода калмыки эти. Как их везли...!? Они умирали, раздетые почти, зимой. У нас там школа в Ракеше была, туда их поместили. То ли неблагонадежные они были, 
я даже не знаю почему. Мы бегали, смотрели на них на этих калмыков» (АЦУиЭ ЛИК АлтГПУ, Гринева Т.А., 1931 г. р.).

В основе фоормиуемого образа этнических депортантов, как правило, лежали сходство/разница в образе жизни и семейно-трудовых традиций, базирующаяся на разной хозяйственно-культурной принадлежности, например, к земледельцам (местное русское население) или скотоводам (депортированные калмыки), «степняков» или горных народов» с их особенностями в системах жизнеобеспечения. Осознание причин «инакости» изменяло отношение от негативного к положительному. Многие респонденты в конечном итоге, осознавая и понимая «инакость» принимали водворенных депортантов, близко подходя к научной оценке. Так, Т.К.Лапутина, 1921 г.р. (Благовещенский район, село Благовещенка) объяснила поведение и образ жизни калмыков следующим образом: «Калмыки, ну, они тоже работали. Но они очень тяжело переносили этот климат, очень тяжело. Они часто болели. Была высокой смертность среди них. А вообще народ... У нас в классе, наверное, человек пять или шесть было ребятишек, калмыков ... Они, конечно, не похожи по психологическому укладу на нас. Они какие-то более свободолюбивые. Они знаете, любили, чтобы пасти скот. Чтобы овец бы пасти... Они как-то любят... степь. Они в степи уходили. Им, вот, какая-то нужна была ширь. Ширь, свобода... Неплохой тоже народ был, но более такой неприспособленный к нашему климату и к нашему труду. Им нужно было [...] степь, овцы. А у нас то все-таки тут было другое животноводство» (АЦУиЭ ЛИК АлтГПУ, Лапутина Т.К., 1921 г.р.).

Респондентами у калмыков, в сравнении с другими этническими депортантами, выделяется стойкое стремление держаться друг друга, которое закреплялось в т.ч. «непохожестью» с местным населением и необходимостью сообща преодолевать экстремальные условия. Это проявлялось не только в стремлении калмыков селиться отдельно, но и в дальнейшем на протяжении всего времени депортации они жили изолированно, формируя обособленные на окраинах сибирских поселений районы. Основным типом жилища калмыков после расселения стали землянки. Ввиду нерешенности жилищных проблем, калмыки, как и многие другие депортированные, «строились» сами: «Жили тут на горе, землянки копали из земли и жили там...» (АЦУиЭ ЛИК АлтГПУ, Ретина А.В., 1928 г.р.). В отличие от немцев, которых массово первыми расселили и для них еще был использован нежилой фронд, в т.ч. дома раскулаченных местных русских крестьян, то при расселении калмыков в 1944 году администрации сел столкнулись с жилищной теснотой. Как говорила про размещение калмыков в их селе Ф.Ф. Молчанова, 1936 г.р.: «... размещали так же - кто примет, там и жили. Да, а где ж тогда? Все вот эти избушки заняты» (АЦУиЭ ЛИК АлтГПУ, Молчанова Ф.Ф., 1936 г.р.).А так как к дерновоземляному строительству вынуждено перешло и местное население это сблизило и депортантов и местных. Консолидации местного русского населения и калмыков также способствовали коллективные хозяйственноскотоводческие традиции, как об этом говорится в следующей цитате: «А они вот... Ну, они любят общество, чтобы быть в каком то коллективе всегда, чтобы с людьми быть. Неплохой тоже народ был, но более такой, неприспособленный к нашему климату и к нашему труду. Вообще..., они безвредные. Вот, армяне они с характером, у них есть стержень».(АЦУиЭ ЛИК АлтГПУ, Быкова Р.К., 1941 г. р.).

Таким образом, нужно отметить, что формируемые образы и представления во многом базировались на кардинальной разнице между 
традиционной культурой земледельцев и скотоводов. Как сказала Т.К. Лапутина, 1921 г.р., «у них обычаи были свои... резко отличались от наших». Среди традиций калмыков-скотоводов, которые создавали определенные преграды более тесному общению она называла особенности традиционной кулинарии калмыков, «во первых они мясо ели, когда оно уже начинает... Запах от него. Вот вывозят - сдохла скотина. Колхоз вывозит на могильник скотский. Вот, а они уже знают, они моментально едут, забирают это мясо и.. [ели]» (АЦУиЭ ЛИК АлтГПУ, Лапутина Т.К., 1921 г.р.). Кроме того, местных удивляло безотходное использовании забитой скотины. В отличие от земледельцев, в традициях питания которых при забое скота многие субпродукты животных мало или совсем не использовались (кишки, хвост, козья или баранья голова, нижняя часть ног копытных), калмыки, являясь наследниками многовековой культуры скотоводов-кочевников сохранили традиции съедать всё, за исключением селезёнки и лимфатических желез. Но, в условиях голода в годы войны могли использовать и мясо погибших животных, которое у земледельцев называлось падаль. Даже если оно уже приобретало специфический запах, который собственно был характерен в целом для излюбленного мяса калмыков - баранины, также как излюбленного блюда - дутур, из кишков и рубца животного, которое пахло специфически. Поэтому многие вещи, традиционные для кочевника степняка, казалось неприемлемым для народов-земледельцев. Хотя традиция совместного застолья с дутуром, практически одинакова с традицией сибирских крестьян при забое сообща готовить и есть «свеженину». Как известно, у русских сибиряков скотоводство было более развито, чем у русских крестьян Европейской России. Следует отметить, что и местное русское население в голодные годы войны использовало «падалину» в пищу (Рыков, 2016). К формированию стереотипов вело непонимание сибиряками, как носителями традиций оседлой культуры земледельцев, и других особенностей бытового поведения калмыков, как носителей культуры скотоводов-кочевников. В частности, среди аргументов стереотипа о нечистоплотности - «одежду стирали редко», «ели всякие отбросы», «идут по дороге, сядут прикроются полами шубы и тут же оправятся». Они отражали восприятие культурнобытовых особенностей скотоводов-кочевников крестьянами-земледельцами.

В целом, полевые материалы показывают, что наиболее консервативными и устойчивыми в комплексе этнических традиций депортантов были пища и традиции питания. Поэтому в тех случаях, когда способы приготовления и состав пищи были понятны для местного земледельческого населения, это облегчало взаимопониманию народов и вело к проникновению иноэтнических традиций в культуру местного или, или наоборот, депортированного населения. Более того, взаимообмен этническими кулинарными традициями вошел в совместную систему преодоления трудностей в 1940-е годы. Например, для местного населения важное значение приобрели навыки приготовления традиционных блюд из зерновых - пшеницы, овса, ржи, кукурузы. Респондент рассказывала: «у нас напротив жили [немцы]. Фамилия была Мешлюнегр, большая семья. Я вот одна у родителей была. Тем более у отца была стабильная работа, мама в магазине работала, в складах [послевоенное время, Т.Щ.]. Материально мы жили неплохо. А они [немцы], их сюда выслали. Они же голые сюда приехали и начинали очень тяжело жить! Вот, я помню хорошо, приду к ним, а бабушка сварит суп, и пшеницу, муку, она пережаривает, пережаривает, а потом выливает и получается, знаете, такая как (...) пюре легкое [аналог русской «болтанки» или «затирухи», 
Т.Щ.]. Вот мы тоже посмотрели, и тоже стали варить такой супчик. Он, вопервых дешевый, и вкусный был. А потом ещё вот знаете, вот, русские, потом стали и другие делать, было такое блюдо, называлось «саломатия». Это бралась вода, кипела, потом туда наливали, сыпали муку, мешали, мешали, мешали, и образовалось тесто заварное. В середине вот так делали углубление, бросали туда масло... и ставили его это блюдо на середину и ложкой ели, так, чтобы кусочек взять и масло маленечко» (АЦУиЭ ЛИК АлтГПУ, Быкова Р.К., 1941 г. р.). Местное население научилось использовать зерновые и для приготовления напитков - чая и «кофе», о чем рассказывала Т.К. Лапутина, 1921 г.р.: «сами [немцы] делали как кофе... Они его не называли кофре. Они называли припс, чай...И вот этот припс они варили в посуде...Варили этот чай - пережареную ячмень или пшеницу, пережареные и растолченные. Это как заварка была» (АЦУиЭ ЛИК АлтГПУ, Лапутина Т.К., 1921 г.р.).

В отличие от депортантов из сельских территорий для крестьянского населения Сибири «инакость» этнических депортантов из Прибалтики, Западной Украины и Белоруссии была, в определенной степени, связана с антогонизмом «крестьян-колхозников» и «горожан-интеллегентов». Поводом к сложным отношениям с этническими депортантами из Прибалтики, Западной Украины и Белоруссии служила их неприспособленность не только к сельскому труду, но и сельской жизни, что часто вело к насмешкам со стороны сельчан. При этом их этническая принадлежность не играла ведущую роль. В отличие от других депортантов, которые органично вливались в деревенское общество, у местного населения сформировался их крайне обобщенный образ: «то ли латыши, толи.... нет, не литовцы... наверное латыши и эстонцы...) (АЦУиЭ ЛИК АлтГПУ, Рябоконев И.В., 1934 г.р.).В материалах интервью проявляются контуры стереотипа «неумех», не приспособленных к сельскому труду: «с теткойходили пешком туда [на лесозаготовки], дак на берегу [увидели]:их заставили готовить дрова. Сплавом лес приплыл - отоплять больницы..., школы..., жилье. Дак, двое на заднице сидят, пилют - дергают эту пилу. А третий - зонтик над ними, держит. В общем они или не хотели, или не приспособленыбыли вообще. Незнаю» (АЦУиЭ ЛИК АлтГПУ, Королева В.В., 1931 г.р.). Для крестьянской девочки такое отношение к труду являлось недопустимым. В соответствии с крестьянскими семейными трудовыми традициями их включали в труд с детства. Поэтому дальше она описывает настоящий труд, сравнивая с работой тех же трех мужчин: «Наша баба пойдет, она вилы возьмет и копну подденет.И попер! И метали [сено] все... Мы с мамой вечерами, поздно, пойдем вот эти кусты обкашивали... Накосим. Вот сколько мне, 12-13 лет, было. Я косила вовсю.А потом натаскаем, жерди подсунешь - палки под капешку, и наносим до половины. Сложим с ей [мамой], наносим опять. И я на стог, а она метать. А че из их [толку] [из пилящих мужчин]?» (АЦУиЭ ЛИК АлтГПУ, Королева В.В., 1931 г.р.).

Влиявшие на взаимовосприятия местных «колхозников» и депортированных не сложившиеся в совместном труде отношения, закреплялись и нехарактерными для сибирской деревни иным поведением в быту и в досуге. Трудно сказать из-за отрывочности информации в интервью что определяло эту «инакость» - традиционность, «цивилизационые черты», интеллигентность, урбанкультура. Как говорили информанты, «о поляках вообще особый разговор. Они были либо музыкантами, либо просто все такие музыкальные. У них в клубе оркестр был - скрипка и мандолина. Они держались обособленно. Женщины такие нарядные, красивые, ухоженные, 
мужчины очень чисто одевались, у них эти тройки были. С собой привезли все. Они держались особняком. Тут ни с кем не знакомились» (АЦУиЭ ЛИК АлтГПУ, Хроменко Н.В., 1947 г.р.).

Историческая память о депортантах 1939-40-го годов показала, что в отличие от депортаций 1941-44 годов консолидации с местным населением не произошло. Более того, как сказала В.В. Королева про депортантов 1939 года, «как только освободили... Ветром сдуло их» (АЦУиЭ ЛИК АлтГПУ, Королева В.В., 1931 г.р.). Р.К. Быкова, 1941 г. р. также подтвердила «Белорусы тоже пораньше уехали, так в основном вот остались немцы... и русские, а эти, все на свою Родину уехали... Ну, они, поляки и греки, почему то быстро уехали» (Топчихинский район, пос. Победим) (АЦУиЭ лИК АлтГПУ, Быкова Р.К., 1941 г. р.). В значительной степени это было связано с тем, что они были предстателями другого мира - западного, с его культурой светскости и развитой социобытовой сферой, а Сибирь, которая, как и другие многие другие аграрные территории СССР отождествляла иной мир - восточный, с традиционностью и патриархальностью во взаимоотношениях и примитивной социобытовой сфрерой, где отсутствовало даже электричество. В данном случае можно говорить, что складывающиеся образы, влияли на фрормирование в традиционном сельским обществе представлений о «своих» и «чужих». За короткий промежуток времени одни стали «своими», другие остались «чужими».

Вместе с тем, нельзя не учитывать и фактор разницы условий выдворения депортантов в 1939 и в 1941 или 1943 годах. Несомненно, сравнение условий депортации поляков в 1939 году и немцев в 1941 году или калмыков в 1944 году показывает появление человеческой жалости к депортантам военного времени со стороны принимающего общества. И эта жалость, и сочувствие являлось важным фрактором фрормируемых образов и складывающихся взаимоотношений. Фактором взаимопомощи становились и одинокость женщин с детьми, и многодетность, и нечеловеческие бытовые условия, т.е. те условия, которые были понятны сельскому жителю и вызывали желание помочь: «мужиков-то не было, а это бабы, а мужиков, наверно, на фрронт взяли, ячет не помню. Че то вотодна женщина, так у нее пятеродетей было, она одна с ними была... Как то все ихлюбили... Идети тут среди нас росли...» (АЦУиЭ ЛИК АлтГПУ, Королева В.В., 1931 г.р.). Поэтому затруднительные условия жизнедеятельности объединяли и ту, и другую часть сельского общества для их преодоления. К этому выводу практически подводит каждое интервью, «ходить не в чем. Обутки были такие, деревянные подошвы, зимой, нихто ж валенки не катал тогда. Некому ж было. Вот так вот было. Плохо было с этой одеждой и с обувью» (АЦУиЭ ЛИК АлтГПУ, Ярошенко М.Н., 1925 г.р.).

Социальная адаптация. В 1940-е годы - годы репрессий и депортаций через социальную адаптацию проходили все группы сельского общества - и депортируемое, и принимающее население. Связано это было с объективными обстоятельствами как вне, так и внутри страны противостояние и схватка супердержав в предвоенное время, война. На уровне сельского или городского сообщества важным фактором являлась государственная политика формирования образов, определившая отдельные социальные группы и целые этносы в категорию «ненадежных». Но если в предшествующее десятилетие политики репрессий (1930-е годы) репрессированные группы формировались преимущественно по социальному принципу (кулаки, казаки, «бывшие» - дворяне), то в 1940-е годы дополнились этническим принципом - этнические депортации. 
Этнические депортанты в сибирской деревне по условиям социальной адаптации делились на тех, для кого они были более или менее благоприятные и на тех, для кого они были крайне неблагоприятными. Под социальной адаптацией понимается вливание мигрантов в принимающее общество на гражданском и повседневно-бытовом уровне. В адаптационных процессах участвовали и мигранты, и местное население. От тех, и от других зависела социальная и общественная комфортность, которая определяла взаимоотношения принимающей и водворенной стороны. Поэтому важно при изучении антропологического содержания депортаций учитывать разницу условий социальной адаптации для разных групп депортантов.

Особенности социальной адаптации немцев. На взаимоотношения местного сельского русского населения и депортируемых немцев влиял сам фракт борьбы с нацистской Германией или, как писали в советской прессе, с «немецкими захватчиками», образ которых под влиянием агитации неверно на бытовом уровне мог переноситься на депортированных. Сама депортация в сибирскую деревню совпала с массовым отступлением советской армии в 1941 году и масштабными потерями, маркируемыми на селе похоронками, поступавшими в каждый сельский дом. Вот как это отражалось в повседневной жизни по воспоминаниям А.В. Леонидовой (Кинотоп), 1937 г.р.: «Видите, нас обзывали всяко. Поезд стоит, а народу на вокзале много и кричат: «Ой, немцев везут, фрашистов везут, у их один глаз на лбу!»... Они нас представляли вообще инопланетянами какими-то» (Поспелихинский район, с. Поспелиха) (АЦУиЭ ЛИК АлтГПУ, Леонидова (Кинотоп) А. В., 1937 г.р.). Сельскому русскому населению, для выстраивания отношений с прибывающими депортированными немцами, необходимо было преодолеть этот эмоциональный фон. Потеря близкого человека на фрронте становилась главным лейтмотивом негативного отношения. А.И. Горбатова, 1930 г.р. рассказывала: «Вот трактористы ребята (немцы) были. Такие работяги. И мы с имя дружили... Любовь крутили. Я прихожу домой. Мама [говорит]: «Ты, однако, с Эрвином ходишь?... Отца убили немцы, ты мне еще с ним щураться будешь!» Взяла веревку, отходила [побила]...» (Зональный район, п. Восход) (АЦУиЭ ЛИК АлтГПУ, Горбатова А.И., 1930 г.р.). Именно по этой причине в сельском обществе, и не только в военное, но и в послевоенное время, осуждали тех русских, которые вступали в браки с немцами. Вот как об этом говорил П.И. Коновалов: «Ну отношение к бракам считалось презренным. Некоторые презирали. Мать моя презирала. Потому что муж у нее на немецкой территории [пропал без вести]..., немцы вроде убили. А я немку брал. Они ненавидели меня и ее. Приходилось мириться с матерью. Ничего, потом согласилась. Если, я ее понимал, значит и мать должна меня понимать. Она даже к детям [от межэтнического брака] относилась хуже, чем к другим детям. Вот сестры дети, она их лучше уважала, чем моих ...» (АЦУиЭ ЛИК АлтГПУ, Коновалов П.И., 1931 г.р.).

Немаловажным фрактором формирования отношения местного населения к депортируемым немцам на первых порах являлось подселение прибывающих немецких семей в дома сельских жителей. С одной стороны, это укорачивало дистанции для сближения в повседневном общении, что являлось положительным фрактором. С другой стороны, вело к бытовым спорам, особенно в условиях перенаселенности сельского жилища и стесненности. Старожил с. Сростки вспоминал: «Я домой прихожу. А у нас семеро ребятишек, да их двое. У нас жили на квартире года два, они в одной комнате, мы в другой. Их привезли, и всё. Нас и дома никого не было, их привезли. 
Сгрузили и сказали, пусть они здесь живут» (АЦУиЭ ЛИК АлтГПУ, Новоскольцев И.Г. 1925 г.р.). М.Ф. Беккер рассказывала: «Были семьи по 18-20 человек в одной комнате. Печка была, ни света, ничего тогда не было. Вот в одном углу одна семья, в другом другая, в третьем - четвертая, еще одна семья на печке, одна между печкой и этой семьей. Вот мы жили 17 человек» (Алтайская деревня, 2012: 159).

Важнейшим фактором эмоционального настроения местного населения являлось воздействие агитационной пропаганды, что усложняло адаптацию немцев. Под воздействием пропаганды и под влиянием эмоционального накала (война с фашистской Германией), немцев в сельском принимающем обществе могли встречать и настороженно, и даже враждебно. Антифашистская компания накладывала негативный отпечаток на встречу немцев. А приходящие с фронта похоронки еще больше ожесточали русское население. М. Е. Йорк вспоминает: «Обзывали нас фашисты... И они (местные) знаете, что нам сказали? Господи, и плач, и смех! В газете тогда про нас пишут и рисуют карикатуры... И когда мы приехали в Савиново, они говорят: «Фу, такие же люди, как мы. А мы думали, как нарисовано в газете, с хвостами» (Зональный район, п. Мирный) (АЦУиЭ ЛИК АлтГПУ, Йорк М. Е., 1923 г.р.). Заметна антифашисткая и агитпроповская, в т.ч. плакатная пропаганда и во фрразе К.П. Геер «Они гадали на нас рогами. Сначала фашистами обзывали» (1932 г.р., с. Стан-Бехтемир, Бийский р-н).

Для самих немцев такой поворот в государственной политике оказался неожиданным, т.к. в их исторической памяти сохранялась и культивировалась информация, когда они по «призыву» российского государства в лице Екатерины Второй приехали в Россию для заселения территорий Поволжья, на пригодных для земледелия землях. Приказ о выселении немцев из Поволжья, опубликованный в газете «Правда» и указанные в нем причины, до сих пор, в историческом сознании немцев вызывают недоумения: «Вот война началась в 41 году. За что нас? Сами мы не знаем. Ужели такие враги были? Рабочий народ был... Но вот... Сталин приказ выпустил. Боялись, что мы перейдем к Германии. Но мы бы не перешли... Ну что я там потеряла? Я там ниче не потеряла. Родители мои, и бабушка, и дедушка - все они тут родились. А я сейчас, например, не хочу в Германию. Я тут родилась, ну хоть не тут [не Алтае, а в Поволжье], но все равно родина - Россия» (АЦУиЭ ЛИК АлтГПУ, Меулер (Шнайдер) А. Б., 1929 г.р.).

Корпус документированных интервью показывает, что ни в общественном сознании советского общества, ни в обрушившейся на советское общество пропаганде, не учитывались особенности такой исторической группы общества, как российские немцы, прибывшие в 1760-е годы в Россию, заселившие плодородные земли, создав одну из самых развитых территорий СССР, офрормленную в советское время в самостоятельную Поволжскую республику. Это облегчало формированию на бытовом уровне ложных ассоциаций с военными немцами фрашистской Германии. Устные источники, созданные на основе исторической памяти, содержат интерпретации депортаций и самими этническими переселенцами, и местными сельскими жителями, что позволяет деликатно работать в этом направлении. Материалы интервью показывают, что пропагандистско-идеологические кампании формировали в условиях войны нелицеприятный образ депортантов, что не могло не влиять на восприятие народами друг друга и на отношение друг к другу. Они определяли интонации и характер межэтнических коммуникаций. Вот как это проявляется в одном из материалов интервью 
респондента из депортированной семьи: «Всяко принимали [местные жители], люди же не понимали... Кто понял, что мы переселенцы. Кто думал, что мы с Германии, привезенные. Даже спрашивали, кто [из нас] у Гитлера рядом жил? А мы даже не видели Германию. Мы же все рожденные в Саратовской области, наши предки завезены 200 лет тому назад, еще Катерина завезла этих немцев... Вот кто презирал, а кто - ничего относились» (АЦУиЭ ЛИК АлтГПУ, Йорк М. Е., 1923 г.р.). Типичным является следующее высказывание: «Ночью приходили, будили нас, вот так по головам пересчитывали, все ли дома: мы же по линии НКВД были, нас контролировали, мы же немцы были, мы были, как их называют? - Враги народа! - Так нас тогда считали. Ну, вот я, например, ни разу не слышала, чтоб нашу семью хоть раз «фашистами» называли, или там «гитлеровцами», никогда. К нам относились очень хорошо, соседи у нас очень хорошие были... помогали» (АЦУиЭ ЛИК АлтГПУ, Беккер М. Ф., 1938 г.р.). Устные свидетельства респондентов из местного населения также содержат следы агитпроповских штампов: «Это было в сорок первом году... приехали... немцы Поволжья... Видишь, там был заговор у них, говорят какой-то, на Волге. Вот оттуда и репрессировали их...» (АЦУиЭ ЛИК АлтГПУ, Коновалов П.И., 1931 г.р.).

Также необходимо учитывать, что важным для социальной адаптации являлся временной фрактор депортирования и прибытия в места водворения реперессированных. Самым неблагоприятным временем как раз и было начало войны - 1941 год, когда была проведена депортация немцев Поволжья. Для немецких депортантов и для русского населения особенно наиболее неблагоприятными были первые месяцы, которые заложили взаимные претензии друг к другу и сопровождались несдержанностью эмоций. Социальный дискомфорт на этапе вселения способствовал фоормиованию в отношениях депортированных и тех, и других эмоционально-враждебного противопоставления «своих» и "чужих», поэтому одной из форм социальной адаптации стали защитные реакции, которые проявляются в воспоминаниях об асоциальном поведении и тех, и других. Например, своеобразная реакция защиты депортантов просматривается в воспоминаниях респондента из коренных сибиряков о том, как насильно переселенные немцы пугали местных колхозников «вот придут наши [подразумевая немцев Германии]». М. К. Останина (1914 г., с.Усть-Калманка) рассказывала: «немцев пригнали. Они злы были сразу. Вот эта немка Роза. Она говорит, силы были бы, я б весь русский народ поперерезала бы... И все равно они уехали...». Отголоски сформировавшейся в первый период неприязни не прошли бесследно, как следствие взаимных обид долгое время встречались на бытовом уровне. Многие местные жители понимали причины такой реакции. Жительница с. Ново-Обинцево Шелаболихинского района так сказала: «У них видимо, обида жила, что они-то ни в чем не виноваты, а на них такое вот было...» (АЦУиЭ ЛИК АлтГПУ, Божанова В.А., 1938 г.р.).

Об этом же говорят сами немцы, которые ощущали двусмысленность и сложность ситуации, в которую попали и немцы, и русские: «И соседи у нас русские, и дружила с русскими, я никогда ни с кем не ругалась. Я даже на мамку обижалася: когда приду с работы, - там она по-немецки, а если со мной подружка [русская], так она со мной по-немецки... Она же [подруга] стоит, она же может обидеться, скажет [подумает]: «Во, че-то говорят про меня». А я говорю: «Мам!». Много не говорила, только: «Мам!». Она сразу глянула, - все, давай по-русски говорить. А так... не знаю, я не могу обидеться: таких у меня враждебностей не было с народом. Все равно, все же мы люди, да? 
Подумаешь там, какой национальности. Господь создал так нас. Мы должны все ...быть вместе» (АЦУиЭ ЛИК АлтГПУ, Леонидова (Кинотоп) А. В., 1937 г.р.).

В условиях непонимания ситуации сформировалась и такая защитная реакция, как неприятие и осуждение межэтнических браков; ограничение досуговых контактов и др. При этом более непримиримыми были отношения взрослых, которые устанавливали табу и ограничения, пытались контролировать своих детей. Но в детской среде любые, в т.ч. и межэтнические, и межгражданские, и межсоциальные границы нарушались довольно быстро. Дети быстрее адаптировались, в т.ч. отказываясь и от этничности, и от языка, и от традиций. В этом смысле самой фрормой социальной адаптации в молодежной среде стал переход с родного немецкого языка на русский и отказ от традиции имянаречения, от германоязычной антропонимики и переход на славянскую. В 1950-60-е годы в нарастании данной тенденции проявлялись попытки депортантов «спрятать свою немецкость», что в свою очередь воспитывало комплекс вины за войну и закрепляла обрусение части немецкого населения. Образно ситуацию, складывающуюся в деревнях вокруг немецкого вопроса, охарактеризовала этническая немка Альма Кинтоп, после замужества перешедшая на русскую фрамилию Леонидова: «Я свое имя страшно не любила: я стеснялась. Стеснялась, что я немка. Знаете, обзывали. Ну, я Альмой не писалася в школе. Я - Алла, меня Алей звали; старшую сестру - она Зельма - ее Зоей звали; Нина Адалина - ее Ниной и звали... Мамку так же звали; теть Мотя ...как порусски похоже Матрена, но она все равно не Мотя, а Матильда; Зара, она Зара - не сменяется; теть Миля (она Эмилия); теть Галя - она тоже не меняется. А вот наши вот менялися. Щас вот у моих сродных сестер и братьев имена... они все: Фрида, Лида, Федя, Вера, Зоя, Иван. Вот сродный брат был только один Эрнст. Отец мой - Вильгельм Вильгельмович. Ну его звали Васей-то уже, ну жена его звала Васей. Это я ж Васильевна, Вильгельмовна. Алла Васильевна, ...а по документам - Альма Вильгельмовна» (АЦУиЭ ЛИК АлтГПУ, Леонидова (Кинотоп) А. В., 1937 г.р.).

Таким образом, одной из форм социальной адаптации немецких депортантов стало «подсознательное» обрусение. В результате социальной адаптации, как показывают материалы интервью, характер взаимоотношений изменялся, отражая эволюцию настроений и социального поведения. Как говорили информанты, «потом, когда мы там пожили ..., и русские стали с нами дружить, и щас у нас... у меня все друзья русские». А общий вывод звучит в следующих словах «Местные относились нормально, никакой вражды не было, чтобы вот я немец, а тот русский. Да сразу признали нас. Были некоторые, что, кто «фашист» там, «немец» обзовется, а потом нет. А мы уже обрусели тут, а что?» (АЦУиЭ ЛИК АлтГПУ, Божанова В.А., 1938 г.р.). Как образно определилась А. В. Леонидова (Кинтоп): «Уже я стала больше русская... Я только знаю в душе, что я чистокровная немка. А веду я себя, как настоящий русский сибиряк...» (АЦУиЭ ЛИК АлтГПУ, Леонидова (Кинотоп) А. В., 1937 г.р.).

Факторы социальной адаптации других этнических депортантов. В отличие от депортированных немцев, как показывает анализ материалов интервью сибирских старожилов, размещение других этнических депортантов, в селах не сопровождалось такой напряженностью. Можно предположить, что это одной из причин являлось непонимание причин их высылки. Устные интерпретации местного населения носят характер предположений. Как в следующей цитате про депортированных чеченцев: «Чеченцы эти, они всё на 
Сталина обижались, что выслали. Боялись, что они воевать будут с нашим русским народом, наверно поэтому. Ну нам не объясняли никогда - што и как. Привезли их и привезли, вот и всё.»(АЦУиЭ ЛИК АлтГПУ, Ярошенко М.Н., 1925 г.р.). Лишь в отдельных случаях рассуждения содержат отголоски газетных публикаций того времени или, уже поздние наложившиеся на мировоззрение сельских жителей современные публикации в СМИ. Как в следующей интерпретации про депортированных калмыков, «Теперь калмыки, сослали тоже их. Они там зашевелились где-то. И их сюда сослали. Им не доверяли, война шла. Тут жили калмыки. Вот эти народности. А потом уже кого тут только нет.»(АЦУиЭ ЛИК АлтГПУ, Лапутина Т.К., 1921 г.р.).

Фактор непонимания и ограниченности информации как раз сыграли благоприятную роль в отношении к участникам разных депортационных волн в период 1939-1949 годов. Так, благоприятную роль в отношении к армянам сыграли и непонятные для сельского населения Алтая аргументы их депортации - дашнаки, партийно-идеологическая борьба, «сослали вот этих армян-дашнаковцев» (АЦУиЭ ЛИК АлтГПУ, Лапутина Т.К., 1921 г.р.). Эти аргументы государственнойполитики не входили в группу значимых для сельского населения. Респонденты быстро находят объяснение причин появления на Алтае в начале войны немцев и совершенно теряются в объяснении депортации армян. «Ведь эти армяне, они не все занимались при оккупации. Ну, всех их, подозрительных, выслали сюда. Они здесь лет пятьшесть пожили... Да, в нашем отделении семей, наверное, десять было армян, и только двое умерли своей смертью. А эти все уехали домой, все живы и здоровы» (Архив ЦУИиЭ ЛИК АлтГПУ, Епихин И.П., 1927 г.р.).

Но, так или иначе, вопросы взаимоотношений в сельском обществе в период массовых депортаций требуют серьезного изучения при бережном обращении с материалами устной истории. Сложности исследований обусловлены этическими проблемами вокруг этой темы.Остроту вопросам по этническим депортациям придавала сама война, расколовшая все общество на «своих» и «чужих». В сельском сибирском обществе часто отношение друг к другу, и к мигрантам определялось участием и потерями членов семьи в войне. Именно с этих позиций местное население часто формировало свое отношение к депортантам. Вот как это проявлялось в рассуждениях про депортированных в 1939 году западных украинцев местной жительницы: «Война началась. Один только из них - коммунист Олежка. Их семья осталася в Карагуже [на Алтае]. А остальные, кого взяли на фронт - они сбежали. И никто из них на фрронте не был. У них там родичи осталися. И они из армии сбежали к этим родичам... И после войны они все-все удрали. Все уехали на Украину. Один Олешка, коммунист бывший, вот он один только был убит... А сама она осталась с четырьма, кажется, ребятишками. А остальные хохлы все убралися... Марина Лысяк сюда писала письмо, вот почему я знаю, что все они живы-то оказалися. А у Марины брата убило» (АЦУиЭ ЛИК АлтГПУ, Шемонаева 3. С., 1925 г.р.).

Формирование диалога народов, разделенных в военный период идеологически и эмоционально, является, с одной стороны, малоизученной и важной темой устноисторических исследований алтайской деревни, с другой стороны, требует от исследователей особой деликатности и бережного обращения с ней в силу особой болезненности вопросов, связанных с межэтническим взаимодействием, как и любых проблем этнической истории. Приходится констатировать, что исследователи до сих пор боятся говорить о трагическом общественном разломе военной поры. Даже в современных 
исследованиях о советской государственной национальной политики в военный период, историки ограничиваются сложившимися стереотипами об интернационализме при умолчании другой стороны политики, связанной со сложными межличностными контактами в сельском обществе в период этнических депортаций.

Хозяйственно-культурная адаптация. В отличие от социальной адаптации, где решающую роль играли субъективные факторы (т.е. зависящие от человека - общества или государства), в основе хозяйственно-культурной адаптации в большей степени лежали объективные факторы, среди них базовые элементы этнических систем жизнеобеспечения и потенциальные возможности жизнедеятельности мест водворения. На влияние повседневных жизненных стратегий на новых территориях значительную роль оказывали иные, сходные или не сходные природно-географические и климатические условия, т.е. то, что называют «кормящий ландшафт». Особенно этот фактор влиял на депортантов, с традиционным и/или патриархальным укладом, что было характерно для народов с высоким процентом сельского населения аграрноразвитых территорий СССР, в отличие от этносов, проживающих по периметру западноевропейской границы, втянутых в цивилизационные процессы глобализации, таких как поляки, литовцы и другие. Сибирский Алтай, как принимающая территория, отличался разнообразием природногеографических условий, что важно было для первых. И сильно отставал в развитии социально-бытовой сферы: отсутствие электричества, радио, база светско-культурного досуга, образовательно-развлекательная среда, архаичные санитарно-гигиенические условия, что было важно для вторых. Кроме того, для второй группы депортантов хозяйственно-культурная адаптация сопровождалась адаптацией к непривычным для них по условиям сельскохозяйственного труда - посуточной занятости в период сельскохозяйственного сезона, преобладанию ручного труда - тяжелого, пыльного, грязного основанного на большой физической силе и др.

Для этнических депортантов с развитыми аграрными навыками, в основе жизнедеятельности которых лежал сельскохозяйственный труд, на первый план вышла адаптация к природно-климатическим и географическим условиям при смене «кормящего ландшафта», иноэтническому и иноконфессиональному окружению. Поэтому и для депортантов-земледельцев, и для скотоводов включались иные механизмы адаптации по сравнению со второй группой мигрантов. При преобладании земледельческого сектора экономики в сельском хозяйстве Алтая легче адаптировались народы-депортанты с земледельческими традициями. К ним относились, например, немцы Поволжья, с развитым земледельческим сектором экономики, трудовыми и семейными земледельческими традициями. Так, во взаимоотношениях русских и немцев традиционные для тех и других навыки работы в поле, на усадьбе способствовали консолидации, тогда как в отношениях к народам-скотоводам сдерживающую роль играл фактор отсутствия у них земледельческих навыков. Рассказчики из местных жителей так и говорили: «Немцы вообще люди рабочие. И девчонки... они работали в звене с нами... И никакой разницы не было... А вот калмыки так себе...» (Щеглова, 2008: 366). Такое восприятие местным населением Алтая отражало контрастность этнических традиций земледельческих и скотоводческих традиций. Это особенно проявляется в отрывке интервью И.Я. Горшкова: «Они [калмыки] не знали, не умели ничего делать по огороду, ни картошку выращивать, ни тем более овощи. Они знали только вот коня, они могли ухаживать за конем, за овцами, и все. Привезли их 
зимой, и были они очень бедные. Если немцы были побогаче нас, местных, то эти были, наоборот, нищие практически, вот у них шуба - и больше ничего нету. Шуба, малахай на голове, обувь какая-то, даже ни пимы, ни валенки, а что-то пошитое, и они очень бедные и голодные были...» (Алтайская деревня, 2012: 139).

Поэтому хозяйственно-культурная адаптация немцев проходила быстрее, калмыков-скотоводов, традиционная система жизнеобеспечения которых отличалась, начиная от жилища до пищи, проходила драматичнее. Вот как описывают респонденты из местного населения попытки калмыков решить вопросы питания с реализацией вкусовых пристрастий и привычек, в основе которых лежали традиции скотоводов-овцеводов: «Ну, калмыки, как, они мясо умели готовить! В больших таких..., как они их называли, казаны. Они мясо, вот, особенно баранину любили [в сибирском скотоводстве преобладало мясомолочное направление]. Они эту баранину покупали где то, ездили... Вот поселки там дальше, Алейского района. Там выращивали овец, были и отары, и кошары были... Туда ездили покупали. Ну, у нас здесь вот, именно здесь, не выращивали баранину, и не варили. Как то, относились к ней [брезгливо]... Вроде запахи там. А когда калмыки готовили, тогда все ели. Очень вкусно они готовили баранину» (АЦУиЭ ЛИК АлтГПУ, Быкова Р.К., 1941 г.р.). Приверженностью к мясным продуктам можно было объяснить и зафриксированные в полевых условиях случаи использования мяса падших животных, как в следующем отрывке «они могли и уже погибших животных брать» (АЦУиЭ ЛИК АлтГПУ, Быкова Р.К., 1941 г.р.).

Для хозяйственно-культурной адаптации этнических депортантов была важна природно-климатическая характеристика территории водворения. В связи с дисперсным расселением депортантов они могли попасть на благоприятные и неблагоприятные территории. Те же калмыки были расселены на территориях с разным рельефом и разным климатом. Более привычными для них были степные территории. Это было замечено местными респондентами: «У калмыков, ну что, хлеб они такой вот не стряпали, как мы, а стряпали эти, приплюснутые такие пышки, теперь. А топились, отапливались они так же, как и мы. Они же степные жители, вот, и точно так же, ходили по степи, собирали этот навоз и отапливались» (АЦУиЭ ЛИК АлтГПУ, Лапутина Т.К., 1921 г.р.).

Важнейшее значение для жизнесохранительного поведения имела сорера применения труда депортированных. Так для калмыков, расселенных в непривычных для них горах, сглаживал условия жизнедеятельности скотоводческий профиль горных колхозов и совхозов. А самой неблагоприятной сферой для них стали лесозаготовки, где отмечалась высокая смертность калмыков. Так, летом 1944 года в соответствии с поступившими указаниями, привезенных в Топчихинский район депортированных калмыков отправили в село Листвянка, в заобской части района, на лесозаготовки, где разместили их в бараках бывшего Верхнеобского отделения Сиблага НКВД. Местами компактного проживания калмыков стало само село Листвянка, леспромхоз, места лесозаготовительных командировок. В воспоминаниях жителя п. Топольный В.М. Шроо, его отец, бывший заключенным Чистюньского лагеря, не раз бывавший на лесозаготовительной командировке в районе Листвянки, рассказывал о калмыках и их ужасной судьбе: при заготовке леса калмыки часто гибли, так как совершенно не умели выполнять данную работу, ведь, как он говорил, «они никогда не видели леса. Падающие стволы калечили и убивали сразу по нескольку человек». И.М. Раков из села 
Клепиково помнил рассказы о чудовищных условиях жизни в Листвянке депортированных калмыков, о большой смертности, в основном из-за травматизма и обморожения. В связи с большим травматизмом и слабой производительностью труда в 1946-1947 годах калмыки были вывезены из Заобского бора и размещены в двух государственных сельскохозяйственных предприятиях района. Это Чистюньский свеклосовхоз и Топчихинское предприятие Заготскот в районе села Песчаное. Для этого в 1946 году в район села Дружба (Чистюньский Свеклосовхоз) привезли мужчин-калмыков для строительства на окраине поселка землянок, на одну-две семьи каждая. А через некоторое время из Листвянки в выстроенные землянки переехали семьи в количестве не более 100-150 человек. Это все, что осталось к 1946 году от прибывших в 1944 году в Топчихинский район более 800 человек депортированных (Родная сторона, 2011: 144).

Поэтому в большой степени адаптация зависела от включенности прибывших депортантов в те отрасли и сферы, в которых они имели умения и навыки. На это нацеливали и государственные директивы по использованию труда в соответствии с профессиональным образованием и навыками. Для этого, как известно, создавались административно-территориальные комиссии, которые должны были подбирать по профессиональным умениям депортантов для вселения в свои административные районы и удовлетворения производственных потребностей. Недаром, местные старожилы, вспоминая расселение депортантов и их включение в общественное производство, говорили «в каждой нации свои [умельцы]. Пастухи - калмыки... Немцы все умеют, все делают. Они технику же очень любят... на тракторах работали и ремонтом занимались. Украинцы, они вот все были шоферами... Ну, в общем, каждый что-то внес, какую-то лепту и в культуру, и в хозяйственно-бытовые условия»(АЦУиЭ ЛИК АлтГПУ, Быкова Р.К., 1941 г. р.). Так, те же размещенные в Чистюнкинском свеклосовхозе калмыки оказались востребованными после расфрормирования в 1953 году Чистюньского лагеря НКВД сельскохозяйственного назначения вследствие чего 27 тыс. гектаров обрабатываемых земель и более 5 тыс. голов скота остались без рабочих рук, т.к. ранее лагерное хозяйство обслуживали более 4 тыс. заключенных. Именно поэтому на бывшее лагерное хозяйство были переброшены вместо заключенных семьи депортированных немцев и калмыков. Житель п. Топольный (бывший 6 лагпункт Чистюньлага) Александр Дорджиевич Дорджиев вспоминает, что в п. Кировский (ранее Комендантск) были привезены для ухода за скотом из Чистюньского свеклосовхоза семьи Бурацак Манкеева, Антона Ширманджиева, Мунер Ширманджиева и другие.

Наиболее успешным проектом по использованию труда репрессированных и депортируемых являлась государственная программа развития свекловодства и производства сахара на юге Западной Сибири. Ярким примером служит история свекловодческого совхоза «Чистюньский» (первое отделение «Дружба», второе отделение «Зеленый») (Самцова, 2011: 154-158), основанного в начале 1932 года как спецпоселение при Чистюньском отдельном лагерном пункте сельскохозяйственного назначения Сиблагаспецпоселение. Он был создан как сырьевая база для открытого в г. Алейск сахарного завода. Комплектование его профессиональными кадрами началось с приезда украинцев-переселенцев, доставки раскулаченных крестьян с Украины, где возделыванием свеклы и производством сахара занимались с начала XIX в. По сталинским планам индустриализации и коллективизации юг Западной Сибири был выбран для переноса опыта в 
Сибирь. Недаром респонденты из старожилов, вспоминая историю Чистюнькинского свеклосовхоза, говорили, что «Свеклосовхоз образовался. Bce управляющие, директора, все были украинцы, Шевченко помню был директор. Все были украинцы. Они вот, собственно, и внедрили [свеклу]. Ну, потому их сюда и прислали, чтобы они выращиванию свеклы научили. Украина же это выращивает сахарную свеклу. Ну, вот это, управляющая отделением, бригадиры, почти все были украинцы. И строители, они [же] все строили... Украинцы, они тоже свою культуры несли, пели. У нас знаете какие были украинские хоры! Они пели такие песни, такие песни красивые украинские!!! Они вот как раз и научили ухаживать за свеклой. Они же с Украины. Они образовывали свеколичные поля и научили обрабатывать поля эти, как полоть, в какое время полоть»(АЦУиЭ ЛИК АлтГПУ, Быкова Р.К., 1941 г.р.).

А в 1940-е годы, с 1939 по 1949 годы, свеклосовхоз и его отделения, Дружба, Зеленое, а также Победим, стали местом этнических депортаций. Полиэтничность свекловодческого поселка Чистюньский отмечается респондентами из местного населения. Р.К. Быкова, 1941 г.р., помнит 1940-е годы ребенком, так рассказывала:«сосланы сюда были... Мы, вот, дети учились в разных классах [1947-1956 гг.]: калмыки, немцы, армяне, были поляки, были греки... Поляки и греки, они недолго здесь жили, ну я не знаю, год - два, потом они разъехались. А вот немцы, украинцы, калмыки, армяне, мы все, они тут жили долго. До тех пор, пока [...] им маленечко стало послабление, им разрешили возвратиться к себе на Родину. Ой, так мы, знаете, в школе жили дружно. Мама же работала в складах, а там был жмых. Жмых - это прессованные отходы от семячек. Вот я значит пойду, карманы наберу этих [...] жмыха. Папа возьмет, на кусочки вот разобьет, нажарим, а голодные дети были все, особенно калмыки [...]. голодные были. Я принесу в класс, всем раздам, в рот [положим] и вот мы на уроках [сидим]. Все в одном классе, все четыре класса. Была у нас учительница, Полина Владимировна, и вот мы сидим урок и этот жмых сосем. Всегда были впроголодь. А если не хватало, то, вот, мы бестолковые были ребятишки, мы вот эти кусочки, я, например, пососу, пососу, а у него [мальчика из калмыков] уже нету, кончился. Маленький кусочек. Я вытаскиваю, передаю. Вот, мы всем классом. Мы не понимали, что он там кламык, или русский, или армянин, так дети все жили дружно. Вот народы все, которые там были, мы жили очень дружно. У нас случился пожар [дом сгорел], так знаете, армяне, они, каждый вечер собирались и нам дом строили. Бесплатно, нисколько, никаких денег, ничего не брали. Просто бесплатно собирались и нам помогали. Тогда мы очень дружно жили, мы не понимали национальности какие-то» (АЦУиЭ ЛИК АлтГПУ, Быкова Р.К., 1941 г. р.).

Этот отрывок несет также очень важную информацию о том, что в массовой исторической памяти населения Алтая армяне остались, прежде всего, как хорошие строители и эти умения стали важнейшим способом адаптации к экстремальным условиям 1940-х годов не только для самих армян, но и местных жителей. Хотя первоначально на Алтае армяне оказались задействованы преимущественно в аграрном производстве, где катастрофически не хватало мужской рабочей силы. Н.П. Гурова (п. Восход) вспоминает, что с ними на полях «армяне работали» (Архив ЦУИиЭ ЛИК АлтГПУ, Гурова Н.П., 1931 г.р.). Армяне достаточно легко вливались в трудовые коллективы. Так, на сельском кладбище с. Дружба (участок старого кладбища) - отделения свеклосовхоза захоронены 20 армян (по записи Топчихинского ЗАГС) (Поздин, 2018). Однако со временем, оценив 
традиционные строительные традиции армян, их стали использовать в строительстве производственных и жилых объектов (Щеглова, 2017). Это говорит и о гибкости этнических систем жизнеобеспечения и том большом вкладе, которые этнические депортанты внесли в развитие регионального сообщества и региональной экономики.

Создание системы преодоления трудностей и взаимовлияние этнических депортантов и местного сельского населения. Взаимовлияние и взаимодействие водворенного и коренного населения в 1940-е годы являлось важнейшим фрактором формирования совместной системы преодоления трудностей для жизнеобеспечения семьи в затруднительных условиях 1940-х годов. (Щеглова, 2018). Как известно, система жизнеобеспечения включала такие базовые элементы повседневности как обеспечение семьи жилищем, питанием, одеждой и др., отвечающие за здоровьесберегающее поведение. В неблагоприятных, затруднительных и/или экстремальных условиях 1940-х годов. это вылилось в борьбу с голодом и с холодом как со стороны депортированных, так и со стороны местного населения.

Новацией в жизнесохранительных практиках обеспечения семьи пищей для сельского русского населения стало освоение новых сельскохозяйственных культур, которые сыграли большую роль в голодные годы войны. Примером являлось освоения кукурузы, как огородной культуры. В свидетельствах респондентов ее распространение связано было либо с украинцами-депортантами 1939 года, которых в Сибири по традиции называли «хохлами», чеченцами. 3.С. Шемонаева вспоминает, что в селе Карагуж Старобардинского района, откуда она родом, кукурузу их научили садить «хохлы»: «Привезли вот кукурузу. Научили нас.» (АЦУиЭ ЛИК АлтГПУ, Шемонаева 3. С., 1925 г.р.). С депортированными местные сельчане связывали не только распространение кукурузы, но и внедрение в семейное огородничество и в колхозное производство других культур, например, фасоли. По словам Н.М. Суртаева, проживавшего в войну в г. Горно-Алтайске, кукуруза появилась в войну: «Ну вот война началась, приехали эвакуированные, они привезли фасоль, привезли кукурузу, до этого здесь этого не было: кукурузы не было, фрасоли не было, соя появилась тоже. ... Ну я сейчас не помню [кто привез], но по-моему были в основном с Прибалтики, мне запомнилось: латыши, литовцы были там, насколько я помню» (АЦУиЭ ЛИК АлтГПУ, Петрушина 3. А., 1937 г.р.).

Но именно распространение кукурузы в повседневных практиках стало важным факторам адаптации сельского населения в условиях недостатка источников пищи. В предгорных районах, по воспоминаниям информантов кукуруза стала вторым по значимости продуктом огородничества, после картошки, а среди злаков - первым (Свидовская; Ковзель, 2018). «Вот кукуруза в войну всю. Выручила всех людей» (АЦУиЭ ЛИК АлтГПУ, Лещев А. Ф., 1926 г.р.). «За палочки работали... А на эту палочку, если че получится - получится урожай, значит что-то дадут на эту палочку, а если не получится урожай - все, надейся на свою кукурузку» (АЦУиЭ ЛИК АлтГПУ, Попова М. И., 1930 г. р.). «Первый хлеб - кукуруза» (АЦУиЭ ЛИК АлтГПУ, Шемонаева З. С., 1925 г.р.). В послевоенное время и колхозы стали садить кукурузу, чтобы обеспечить колхозников зерном кукурузы, которое стало заместительным продуктом для земледельцев при недостатке других злаковызх зерновых культур (рожь, пшеница и др.). А.С. Долгова описывает момент из жизни в с. Никольское Старобардинского района, когда она впервые увидела этот злак: «Появилась 
[кукуруза], даже я уже большая была, у нас кукурузы не было..... А у нас отец там, на гору зайдешь, ... и посеяна была кукуруза. И он ходил и нам три кукурузины или четыре ли принес - красна, да желта то кукуруза. Принес, а мы - вместо игрушек [использовали]... Это игрушек никаких не было, так мы играли ... Утром встали, а у нас две кукурузины осталось - те съели» (АЦУиЭ лИК АлтГПУ, Долгова А. С., 1923 г.р.).

Устные свидетельства показывают, что в условиях архаизации и марганализации сельского общества под влиянием войн и репрессий процессы взаимодействия с депортированными по созданию системы преодоления трудностей и борьбы с холодом и голодом фактически базировались на взаимопомощи и взаимообмене умениями и навыками. Взаимообмен адаптационных практик часто проходил по границе между культурой степи и культурой лесостепи, культурой гор и культурой тайги, обусловленных возможностями «кормящего ландшафта». В результате совместного преодоления трудностей степные традиции степи проникали в культуру сибирского сельского населения как носителей культуры леса и наоборот. Зоя Семеновна Шемонаева рассуждала об украинских депортантах: «Во-первых, они не умели и не знали, что такое дрова. Они привозили солому, дальше... траву и топилися ночью этой соломой... Вот так вот эту печку делают, снопы толкают и толкают их. А у нас же Сибирь, зимой хоть затолкайся. И вот, что сделают [в холодной избе]. Спать - если большая семья - негде, комнату же одну [избы]. В деревне же не было хором-то никаких. Они солому стелят на пол, покрывают своими этими мендирюшками - половичками и спят на этой соломе, а утром ее значит снопами и вытопят печь. На следующий день опять расстилают - спят, утром встают соломой топились. Потом научились..., что дрова надо в Сибири». Она же вспоминала, «на работу идут летом босяком. Смажут дёгтем или чем-то, чтобы они задубели. Но это было только один сезон, потом они уже все это бросили и жили по-русски»(АЦУиЭ ЛИК АлтГПУ, Шемонаева 3.С., 1925 г.р.).

Межэтнический диалог в 1940-е годы существенно повлиял на развитие этнических культур и в сфере питания, и в сфере жилищного строительства и обустройства, и в трудовых, и в семейных традициях. Так, под влиянием немцев в обустройстве спальных мест русских сибиряков наряду с дерюжками и рядном уже в послевоенное время в быт прочно вошли перины. Как описывала Р.К. Быкова (Топчихинский район, пос. Победим) «для гостей была перина, тоже сами делали. Они [немцы] все обдирали, подушечки делали. У нас у русских, это нет, у нас, перья кругом валяются, никто не видит. А я помню, вот, бабушка была, соседка [немка]... Бабушка придет..., она у нас все в ограде перышки соберет, и гусинные и все. Все пообрежет»(АЦУиЭ лИк АлтГПУ, Быкова Р.К., 1941 г.р.).

Маркером усиления иноэтнических традиций в среде русских старожилов являлось использование глины, которая, став мощным подспорьем в жилищном строительстве и обустройстве, заменила в культуре русских такие элементы хозяйственно-бытовой идентичности как срубное строительство. Депортированные, особенно немцы, украинцы, армяне и другие широко использовали глину, как основной строительный материал (литые и саманные дома) и глиняный раствор для связки нестроевого материала при каркасном строительстве (в т.ч. связки дерна или камыша). Фактически в тех случаях, когда депортированным при расселении не предоставлялись «пустые дома» (как правило, они были почти во всех селах после мощной волны раскулачивания русских сибиряков и ссылки их семей на «севе'ра» Сибири - 
Нарым, Туруханск) или не подселяли в дома местных жителей, они проходили две ступени обустройства, также, как и русское население Сибири в местах высылки (Щеглова, 2018). На первом этапе многие, особенно немцы и калмыки, сооружали временное земляное жилище - разного рода землянки. На втором этапе, особенно после войны, сооружали уже постоянное жилище, как правило, саманное, глинобитное или каркасное. Эти традиции быстрого и доступного для женщин жилища оказались востребованными сибирским сельским обществом, т.к. оно было отстранено от заготовок срубного материала (национализация леса), а в годы войны и в послевоенное время сибирская деревня с преимущественно женским населением не имела фризической силы для работы с таким тяжелым материалам как дерево. В экспедициях зафриксированы сотни устных свидетельств о «найме», «помощи», «помочах» немцев или украинцев по использованию глины для жилищного обустройства (глинобитные дома или оштукатуривание срубов), и армян для саманного строительства. Достаточно привести одно высказывание (АЦУиЭ ЛИК АлтГПУ, Кошкарова Н.С., 1926 г.р.) (Усть-Пристанский район, с. УстьПристань) «Такие литые дома у йих были [немцев], там возле могилок, туда далёко, там большие дома были. Там наверно, тоже из кирпичей делали они эти дома-то [респонденты часто путают саманную и литую технологию строительства]. Они богато жили эти немцы-то [имеет в виду, что все построились в селе]. А мы-то где? Глину, лепили эту избушку. Вот и мама нанимала этих бабок. Они - мастера. Себе делали и сами дворы. Да литые каки-то были дома у их там. Щас ведь деревянное всё делают. Щас не строются. И нанимались эти немцы. Они мастера. И мужики мож хорошие были. И я знаю, вот две бабки были. Она [мама] привела [бабок]. И они эту избушки помогали, делали, из кирпичей. Такие [саманы] делали. И глину месили. Я помню, мы ногами месили, они в вёдра складывали и туда таскали, делали. А, себе они дома делали, с мужиками там... Каки-то литые делали и большие дома [у сибирячек - избы]. Ну они богато жили немцы. Как-то. И с мужиками они жили [имеет в виду, что сельских русских мужиков «повыбивало» на фронте, а муское накселение в той или иной степени вернулось с труармий]. А эти одиночки, они все одиночки [вдовы] так остались. И лачуги там были тоже, каки-то землянки тоже. А кто с мужиками, так они и богато жили, вон каки дома большие делали». М.Д. Кожемякин (1931 г.р.) так и говорит: «Армяне это выдумали, такое строительство (саманное). Саман делали из соломы и глины. С обоих сторон обмажут, выбелят» (АЦУиЭ ЛИК АлтГПУ, Кожемякин М.Д., 1931 г.р.).

Полевые исследования показали, что при расселении нескольких семей в селах, депортанты стали строиться компактно на окраинах поселений, формируя в русских селах этнические края. «мне бабушка говорила, что у нас прям немецкая улица даже как то... вот туда от ветучастка [ветеринарного] вот туда дальше они селились. И вот и саманные домики первые ставили. Вот саман, глина вот эта ...»(АЦУиЭ ЛИК АлтГПУ, Коротких Ю. К., 1932 г.р.).В устных свидетельствах повсеместно подчеркивается, что землянки, саманки, бараки депортированных находились за определенной чертой оседлости русских старожилов. С одной стороны, это было объективно, поскольку строились на свободном месте, с другой - в этом проявлялась определенная тяга к консолидации в иноэтнической среде. Так, в Урожайном «армяне жили на той стороне лога. Пруд, по той стороне жили все. Армяне жили. Молдаване отдельно жили. Русские тоже жили. Вместе же не будем жить с ними. Каждая семья к своей кучке. Скажем, армяне там. Там, молдаване. Тама калмыки 
строились себе» (АЦУиЭ ЛИК АлтГПУ, Кожемякин В.Г., 1931 г.р.; (АЦУиЭ лИК АлтГПУ, Чепурных Т.А., 1926 г.р.). Закреплению консолидации в период расселения, как между поселениями, так и внутри сел, способствовала и устойчивость национальной бытовой и праздничной культуры. Об этом хорошо помнят старожилы: «армяне свои круга танцевали, молдаване свои, а калмыки ходили по защитке».

Строительство депортированными жилища привели к большому его разнообразию в русских селах юга Западной Сибири. Это многообразие касалось не планировки и типов жилища, среди которых возобладали в 193040-е годы одно и двухкамерные жилища (избы и пятистенки), а строительных материалов и технологий, внутренней и внешней отделки стен жилищ, сооруженных из нестроевого материала. Возникшее под влиянием депортаций многообразие сельского жилища в сибирской деревне по строительному материалу делилось на «земляные» («землянка», «пластянка», «дернуха»), глиняные («мазанка», «самануха» или «саманник», «литуха»), камышитовые (каркас из камыша), плетенные (из ветлы, акации, ивы). Стены таких жилищ часто изнутри и снаружи мазались глиной и для утепления, и для выравнивания стен и с эстетическими целями. Внутренняя и внешняя штукатурка проникла и в традиционное срубное жилище, которое стало утеплятся или ремонтироваться с использованием глины и соломы. И главными проводниками были депортированные. Респонденты из коренных жителей таки говорили, «Немцы научили сщикатурить» (АЦУиЭ ЛИК АлтГПУ, Привалова А.И., 1913 г.р.). А в ухудшавшихся после войны условиях жилищного обустройства русское население, в том числе под влиянием депортантов, повсеместно переходило на подручные строительные материалы (глина, солома, камыш, чаща), включало традиции штукатурить («мазать») стены снаружи и изнутри. С этого времени штукатурка распространилась и на старожильческие срубные дома (Щеглова, 2016).

Описание вкраплений иноэтнических традиций в ту или иную культуру народов под влиянием депортаций можно продолжить. Одно бесспорно, что эти антропологические аспекты должны стать самостоятельными в исследовании депортаций. Исследователям предстоит изучить традиции и новации, трансформации этнических культур, ее подстрахующую роль в экстремальных условиях и т.д. Можно только предварительно предположить о степени изменчивости и/или устойчивости тех или иных элементов этнических культур. Одни элементы задерживались навсегда, другие надолго, третьи - на время затруднительных условий проживания. В частности, этнографы к наиболее консервативным относят пищу и питание. Есть подтверждения этому и в полевых материалах по депортациям, когда чеченцы везли с собой кукурузу, а калмыки искали источники баранины.

В сельских же поселениях русских юга Западной Сибири осталось много следов влияния депортантов. В этом отношении было бы интересно посмотреть, а что «с собой увезли» из традиционной культуры сибиряков депортанты после реабилитации. Для каких народов новации имели устойчивый характер и почему, а у каких они не задержались. Эта обратная связь могла бы быть реализована в совместных проектах сибирских исследователей и исследователей территорий исхода депортантов, а теперь уже и ряда самостоятельных государств. Имеющиеся немногочисленные свидетельства дают интересную картину. Так известный алтайский краеведисследователь С.В. Поздин рассказывал, что когда он жил 5 лет в Калмыкии, то чувствовал особое отношение старшего поколения, пережившего 
депортацию на Алтай в благодарность за ту поддержку, которую оказало местное население. Вот как он говорил: «старые люди, кто пережил ссылку в Сибирь, очень хорошо относились ко мне, как к русскому. А те, кто был сослан в свеклосовхоз Чистюньский, или родились здесь в п. Дружба, вообще называли меня земляком. Но, вот поколение молодое, или мои сверстники, которые знали о репрессиях только по рассказам даже иногда не здоровались со мной. Так мои соседи Бадмаевы, мои сверстники, прожили со мной пять лет через забор и не разу даже не поздоровались». Очень интересной является и его оценка влияния русской культуры на вернувшихся с депортации: «еще я действительно замечал, что калмыки, старые жители нашего села, в основном я знал пожилых женщин (соседи по улице), возделывают довольно большие огороды, где садят картошку, различные овощи. И даже имеют небольшие сады с фрруктовыми деревьями и полисадники с цветами перед домом. Более молодые семьи землю вокруг дома и огород почти не возделывают. На хотоне весь участок у такой семьи заросший травой и по середине этого футбольного поля стоит кибитка для гостей и машина. Вот и всё что окружает дом, кроме забора. Здесь [Калмыкии] так же проявляется взаимопроникновение русской кухни, русских традиций в культуру степняка. Так бабушка Горяева, жила три дома от нас по улице, очень любила варить борщ. Её внук Минька, дружил с моим сыном и то же очень не прочь был отведать нашего борща. Бабушка приучила. Он рос с бабушкой».

Таким образом, подводя итоги исследованию исторической памяти об этнических депортациях с 1939 до 1949 годов на территорию юга Западной Сибири необходимо подчеркнуть, что экстремальность условий жизнедеятельности существовала и для группы насильственно водворенных депортантов, и для принимающего сельского колхозно-совхозного социума вследствие ликвидации семейного земледелия и скотоводства, налогового бремени войны и предвоенных репрессий. Вместе с тем сравнительный анализ показал, что для одних групп этнических депортантов эти условия были чрезвычайно тяжелыми, для других трудными, для третьих затруднительными. На это влияли и время депортации, и обстоятельства водворения, и государственная политика. Это содержится в исторической памяти, в том числе, и в форме образов, мифологем, агитпропов и идеологем. Поэтому, рассматривая вопросы социальной адаптации, которые состояли в преодолении негативного эмоционального фона, взаимных обид и претензий, особенно выделяются немцы, для которых депортация до сих пор ассоциируется с незаслуженной и непонятной агрессией государства, обида на которое до сих пор живет в их сознании. Тогда как отношения с местным населением, пережив сложный период, усугубленный массовой гибелью на фронтах русских сибиряков, которая маркировалась приходящими похоронками, вступили в полосу общественного комфорта. Для остальных депортантов благоприятными факторами водворения являлись невнятные аргументы их депортаций, что в конечном итоге в интерпретации сибиряков свело все обвинения государства к фразе «зашевелились».

К важнейшим выводам исследования относится утверждение, что восприятие и дальнейшие взаимодействия во многом определялись хозяйственно-культурными традициями депортируемых, которые оказались в иных природно-климатических условиях; иноэтническом и инокультурном пространстве. Хозяйственно-культурная адаптация состояла в формирование базовых элементов системы жизнеобеспечения семьи - жилище и пища на новом месте. Для одних уклад жизни и традиционная система 
жизнеобеспечения (немцы, украинцы) позволили быстрее вливаться в местное земледельческое сообщество, благодаря навыкам домашнего огородничества и полевого земледелия. Для других образ жизни и семейные трудовые традиции не только создавали трудности в общении, но и не выполнили подстрахующую роль в экстремальных для депортантов условиях. В т.ч. и по этой причине (автор учитывает и разницу в условиях водворения разных департационных волн), драматично складывалась жизнь калмыков, как носителей традиций кочевого скотоводства. Делается также вывод, что благодаря хозяйственно-культурному взаимообмену формировалась единая система преодоления трудностей по борьбе с холодом и голодом с взаимопроникновением иноэтнических элементов в традиционные культурные стандарты.

Новационным можно считать вывод о влиянии на адаптационные повседневные практики множественной идентичности депортантов. Исследование показало, что идентичность депортантов проходила не только по границе земледельческих или скотоводческих, степных или горных народов, но и по границе село - город, крестьяне или интеллигенция, запад - восток. К таким утверждениям приводит анализ исторической памяти о депортации народов Прибалтики (литовцы, эстонцы), Западной Украины и Западной Белоруссии (поляки, украинцы, белоруссы) в 1939- 1940 годах и в послевоенное время.

Очень важным выводом является и влияние депортантов не только на хозяйственно-бытовую жизнь сельской семьи, но и на производственное и общественное развитие сибирского села. К ним можно отнести ряд успешных проектов по развитию местного сельскохозяйственного производства (украинцев в становлении свекловодства, армян в строительстве, калмыков в скотоводстве, чеченцев по возделыванию кукурузы и т.д.).

\section{Әдебиеттер тізімі / Список литературы}

1. Алтайская деревня, 2012 - Алтайская деревня в рассказах её жителей / Управление Алтайского края по культуре и архивному делу ; науч. ред.: Т. К. Щеглова, Л. М. Дмитриева ; под ред. Л. А. Вигандт. Барнаул : Алтайский Дом печати, 2012. 447 с.

2. АЦУИиЭ ЛИК АлтГПУ (архив Центра устной истории и этнографии Лаборатории исторического краеведения), Коновалов П. И., 1931 г. р. - Архив ЦУИиЭ ЛИК АлтГПУ. Ф. ИЭЭ, 2003. Коновалов П. И., 1931 г. р., с. Калмыцкие Мысы, Поспелихинский район

3. АЦУИиЭ ЛИК АлтГПУ, Ретина А. В., 1928 г. р. - Архив ЦУИиЭ ЛИК АлтГПУ. Ф. ИЭЭ, 1996. Ретина А. В., 1928 г. р., с. Забродино, Тальменский район.

4. АЦУИиЭ ЛИК АлтГПУ, Молчанова Ф. Ф., 1936 г. р. - Архив ЦУИиЭ лИК АлтГПУ. Ф. ИЭЭ, 2015. Молчанова Ф. Ф., 1936 г. р., п. Благовещенка, Благовещенский район,

5. АЦУиЭ ЛИК АлтГПУ, Привалова А.И., 1913 г.р. - Архив ЦУиЭ лИК АлтГПУ. Ф. ИЭЭ, 1993. Привалова А.И., 1913 г.р., с. Точильное, Смоленский район.

6. АЦУиЭ ЛИК АлтГПУ, Йорк М. Е., 1923 г.р. - Архив ЦУиЭ ЛИК АлтГПУ. Ф. ИЭЭ, 2002. Йорк М. Е., 1923 г.р. п. Мирный, Зональный район.

7. АЦУиЭ ЛИК АлтГПУ, Горбатова А.М., 1930 г.р. -Архив ЦУиЭ лИК АлтГПУ. Ф. ИЭЭ, 2002. Горбатова А.М., 1930 г.р., п. Восход, Зональный район.

8. АЦУиЭ ЛИК АлтГПУ, Гурова Н.П., 1931 г.р. - Архив ЦУиЭ лИК АлтГПУ. Ф. ИЭЭ, 2002. Гурова Н.П., 1931 г.р., п. Восход, Зональный район

9. АЦУиЭ ЛИК АлтГПУ, Кожемякина М.Д., 1932 г.р. -Архив ЦУиЭ ЛИК АлтГПУ. Ф. ИЭЭ, 2002. Кожемякина М.Д., 1932 г.р., п. Урожайный, Зональный район.

10. АЦУиЭ ЛИк АлтГПУ, Кожемякин В.Г., 1931 г.р. - Архив ЦУиЭ лИк АлтГПУ. Ф. ИЭЭ, 2002. Кожемякин В.Г., 1931 г.р., п. Урожайный, Зональный район.

11. АЦУиЭ ЛИК АлтГПУ, Чепурных Т.А., 1926 г.р. - Архив ЦУиЭ лИК АлтГПУ. Ф. ИЭЭ, 2002. Чепурных Т.А., 1926 г.р., п. Урожайный, Зональный район.

12. АЦУиЭ ЛИК АлтГПУ, Епихин И.П., 1927 г. р. - Архив ЦУиЭ лик АлтГПУ. Ф. ИЭЭ, 2003. Епихин И.П., 1927 г. р., с. Первомайское, Бийский район. 
13. АЦУиЭ ЛИК АлтГПУ, Кузовлева О.Е., 1919 г.р. - Архив ЦУиЭ лИК АлтГПУ. Ф. ИЭЭ, 2003. Кузовлева О.Е., 1919 г.р., с. Малоенисейское, Бийский район.

14. АЦУиЭ лИК АлтГПУ, Новоскольцев И.Г., 1925 г.р. - Архив ЦУиЭ лИк АлтГПУ. Ф. ИЭЭ, 2003. Новоскольцев И.Г., 1925 г.р., с. Сростки, Бийский район.

15. АЦУиЭ ЛИК АлтГПУ, Ковалик И. Н., 1927 г.р. -Архив ЦУиЭ ЛИК АлтГПУ. Ф. ИЭЭ, 2004. Ковалик И. Н., 1927 г.р., с. Красный Партизан, Чарышский район.

16. АЦУиЭ ЛИК АлтГПУ, Хроменко Н.В., 1947 г.р. -Архив ЦУиЭ лИК АлтГПУ. Ф. ИЭЭ, 2004. Хроменко Н.В., 1947 г.р., с. Красный Партизан, Чарышский район.

17. АЦУиЭ ЛИК АлтГПУ, Божанова В.А., 1938 г.р. -Архив ЦУиЭ ЛИК АлтГПУ. Ф. ИЭЭ, 2005. Божанова В.А., 1938 г.р., с. Ново-Обинцево, Шелаболихинский район.

18. АЦУиЭ ЛИК АлтГПУ, Леонидова (Кинотоп) А. В., 1937 г.р. - Архив ЦУиЭ лИК АлтГПУ. Ф. ИЭЭ, 2009. Леонидова (Кинотоп) А. В., 1937 г.р., с. Поспелиха, Поспелихинский район.

19. АЦУиЭ ЛИК АлтГПУ, Меулер (Шнайдер) А. Б., 1929 г.р. - Архив ЦУиЭ ЛИК АлтГПУ. Ф. ИЭЭ, 2012. Меулер (Шнайдер) А. Б., 1929 г.р., с. Зятьково, Панкрушихинский район.

20. АЦУиЭ ЛИК АлтГПУ, Беккер М. Ф., 1938 г.р. -Архив ЦУиЭ ЛИК АлтГПУ. Ф. ИЭЭ, 2012. Беккер М. Ф., 1938 г.р., с. Велижанка, Панкрушихинский район.

21. АЦУиЭ ЛИК АлтГПУ, Лапутина Т.К., 1921 г.р. -Архив ЦУиЭ лИК АлтГПУ. Ф. ИЭЭ, 2015. Лапутина Т.К., 1921 г.р., с. Благовещенка, Благовещенский район.

22. АЦУиЭ ЛИК АлтГПУ, Ярошенко М.Н., 1925 г.р.- Архив ЦУиЭ лИК АлтГПУ. Ф. ИЭЭ, 2015. Ярошенко М.Н., 1925 г.р., с. Благовещенка, Благовещенский район.

23. АЦУиЭ ЛИК АлтГПУ, Коротких Ю.К., 1932 г.р.- Архив ЦУиЭ ЛИК АлтГПУ. Ф. ИЭЭ, 2016. Коротких Ю.К., 1932 г.р., с. Усть-Чарышская Пристань, Усть-Пристанский район.

24. АЦУиЭ ЛИК АлтГПУ, Гринева Т.А., 1931 г.р.-Архив ЦУиЭ ЛИК АлтГПУ. Ф. ИЭЭ, 2016. Гринева Т.А., 1931 г.р., с. Усть-Чарышская Пристань, Усть-Пристанский район.

25. АЦУиЭ ЛИК АлтГПУ, Кошкарова Н.С., 1926 г.р.- Архив ЦУиЭ ЛИК АлтГПУ. Ф. ИЭЭ, 2016. Кошкарова Н.С., 1926 г.р., с. Усть-Чарышская Пристань, Усть-Пристанский район.

26. АЦУиЭ ЛИК АлтГПУ, Шемонаева З.С., 1925 г.р. - Архив ЦУиЭ лИК АлтГПУ. Ф. ИЭЭ, 2017. Шемонаева 3.С., 1925 г.р., с. Красногорское, Красногорский район.

27. АЦУиЭ ЛИК АлтГПУ, Королева В.В., 1931 г.р. - Архив ЦУиЭ лИК АлтГПУ. Ф. ИЭЭ, 2017. Королева В.В., 1931 г.р., с. Сосновка, Красногорский район.

28. АЦУиЭ ЛИК АлтГПУ, Васютин И.А., 1928 г.р. - Архив ЦУиЭ ЛИК АлтГПУ. Ф. ИЭЭ, 2017. Васютин Иван Алексеевич, 1928 г.р., с. Усть- Иша, Красногорский район.

29. АЦУиЭ ЛИК АлтГПУ, Петрушина 3. А., 1937 г.р. - Архив ЦУиЭ ЛИК АлтГПУ. Ф. ИЭЭ, 2017. Петрушина 3. А., 1937 г.р., с. Усть-Кажа, Красногорский район.

30. АЦУиЭ ЛИК АлтГПУ, Лещев А. Ф., 1926 г. р. - Архив ЦУиЭ ЛИК АлтГПУ. Ф. ИЭЭ, 2017. Лещев А. Ф., 1926 г. р., с. Лебяжье, Красногорский район.

31. АЦУиЭ ЛИК АлтГПУ, Попова М. И., 1930 г. р. - Архив ЦУиЭ ЛИК АлтГПУ. Ф. ИЭЭ, 2017. Попова М. И., 1930 г. р., с. Лебяжье, Красногорский район.

32. АЦУиЭ ЛИК АлтГПУ, Долгова А. С., 1923 г.р. - Архив ЦУиЭ лИк АлтГПУ. Ф. ИЭЭ, 2017. Долгова А. С., 1923 г.р., с. Красногорское, Красногорский район.

33. АЦУиЭ ЛИК АлтГПУ, Быкова Р.К, 1941 г.р. - Архив ЦУиЭ ЛИК АлтГПУ. Ф. ИЭЭ, 2018. Быкова Р.К, 1941 г.р., пос. Победим, Топчихинский район.

34. АЦУиЭ ЛИК АлтГПУ, Рябоконев И.В., 1934 г.р. - Архив ЦУиЭ ЛИК АлтГПУ. Ф. ИЭЭ, 2017. Рябоконев Иван Васильевич, 1934 г.р., с. Красногорское, Красногорский район.

35. Самцова, 2011 - Самцова Е.В. 80 лет со времени образования совхоза «Чистюньский» Топчихинского района Алтайского края // Алтайский край, 2012 г.: календарь знаменат. и памят. дат. Барнаул, 2011. С. 154-158.

36. Поздин, 2018 - Поздин С.В. Репрессированные армяне в Топчихинском районе // Топчихинский район - краеведческий сайт. [Электронный ресурc] / URL: http://topkraeved.ru/category/istoriya/ (Дата обращения 05.04.2019).

37. Родная сторона, 2011 - Родная сторона: сборник по истории и культуре Топчихинского района. Барнаул, 2011. С. 142-149.

38. Рыков, 2016 - Рыков А. В. Использование мяса павших животных в питании русского крестьянства Алтайского края в годы Великой Отечественной войны // Тобольск научный - 2016 : Материалы XIII Всероссийской научно-практической конференции (с международным участием) (г. Тобольск, 10 -11 ноября 2016 г.). Тобольск, 2016. С. 272-275.

39. Свидовская; Ковзель, 2018 - Свидовская А.С., Ковзель А.В. Кукуруза в питании жителей Алтайского края в годы Великой Отечественной войны (по полевым материалам 2017 г.) // Частное и общественное в повседневной жизни населения России: история и современность (региональный аспект). Сборник материалов междунар. науч. конф. / под отв. ред. С.В. Степанов. Санкт-Петербург, 2018. С. 159-165.

40. Сыщенко , 2007 - Сыщенко А.Г. Немцы в Сибири: По документам НКВД, МГБ, МВД СССР 1943-1956 гг. Барнаул, 2007. 623 с. 
41. Щеглова, 2017 - Щеглова Т.К. Принимающий алтайский социум и депортированные армяне в контексте перманентных репрессий и депортаций 1930-1940-х гг.: образы и культурное взаимодействие // Вестник археологии, антропологии и этнографии. 2017. № 2 (37) С. 137-145.

42. Щеглова, 2016 - Щеглова Т.К. Традиции и новации в обустройстве жилой среды русского населения юга Западной Сибири в контексте исторического развития (1860-1980-е гг.) // Традиционная культура. 2016. № 1. С. 164-174

43. Щеглова, 2015 - Щеглова Т.К. Этнографияя русского крестьянства юга Западной Сибири в XX столетии: Культура жизнеобеспечения в годы Великой Отечественной войны: Научные и методические материалы. Барнаул: Азбука, 2015. 132 с.

44. Щеглова, 2018 - Щеглова Т.К. Культура и быт русского сельского населения юга Западной Сибири в 1930-1950-х гг.: жилище, пища, одежда, семейные и трудовые традиции : монография. Барнаул : АлтГПУ, 2018. 508 с.

45. Щеглова, 2008 - Щеглова Т.К.. Деревня и крестьянство Алтайского края в XX веке. Устная история: монография. Барнаул : БГПУ, 2008. 527 с.

46. Щеглова, 2011 - Щеглова Т.К. Устная история: учебное пособие для студентов вузов. Барнаул : АлтГПА, 2011. 363 с.

\section{References}

Altajskaya derevnya, 2012 - Altajskaya derevnya $v$ rasskazah eyo zhitelej [Altai village in the stories of its inhabitants] / Upravlenie Altajskogo kraya po kul'ture i arhivnomu delu ; nauch. red.: T. K. Shcheglova, L. M. Dmitrieva ; pod red. L. A. Vigandt. Barnaul : Altajskij Dom pechati, 2012. 447 s. (in Rus.)

ACUliE LIK AltGPU, Konovalov P. I., 1931 g. r. - Arhiv CUliE LIK AltGPU. [Archive of the Center for Oral History and Ethnography of the Laboratory of Historical Local History of the Altai State Pedagogical University]. F. IEE, 2003. Konovalov P. I., 1931 g. r., s. Kalmyckie Mysy, Pospelihinskij rajon. (in Rus.)

ACUliE LIK AltGPU, Retina A. V., 1928 g. r. - Arhiv CUliE LIK AltGPU. [Archive of the Center for Oral History and Ethnography of the Laboratory of Historical Local History of the Altai State Pedagogical University]. F. IEE, 1996. Retina A. V., 1928 g. r., s. Zabrodino, Tal'menskij rajon. (in Rus.)

ACUliE LIK AltGPU, Molchanova F. F., 1936 g. r. - Arhiv CUliE LIK AltGPU. [Archive of the Center for Oral History and Ethnography of the Laboratory of Historical Local History of the Altai State Pedagogical University]. F. IEE, 2015. Molchanova F. F., 1936 g. r., p. Blagoveshchenka, Blagoveshchenskij rajon. (in Rus.)

ACUiE LIK AltGPU, Privalova A.I., 1913 g.r. - Arhiv CUiE LIK AltGPU. [Archive of the Center for Oral History and Ethnography of the Laboratory of Historical Local History of the Altai State Pedagogical University]. F. IEE, 1993. Privalova A.I., 1913 g.r., s. Tochil'noe, Smolenskij rajon. (in Rus.)

ACUiE LIK AltGPU, Jork M. E., 1923 g.r. - Arhiv CUiE LIK AltGPU. [Archive of the Center for Oral History and Ethnography of the Laboratory of Historical Local History of the Altai State Pedagogical University]. F. IEE, 2002. Jork M. E., 1923 g.r. p. Mirnyj, Zonal'nyj rajon. (in Rus.)

ACUiE LIK AltGPU, Gorbatova A.M., 1930 g.r. - Arhiv CUiE LIK AltGPU. [Archive of the Center for Oral History and Ethnography of the Laboratory of Historical Local History of the Altai State Pedagogical University]. F. IEE, 2002. Gorbatova A.M., 1930 g.r., p. Voskhod, Zonal'nyj rajon. (in Rus.)

ACUiE LIK AltGPU, Gurova N.P., 1931 g.r. - Arhiv CUiE LIK AltGPU. [Archive of the Center for Oral History and Ethnography of the Laboratory of Historical Local History of the Altai State Pedagogical University]. F. IEE, 2002. Gurova N.P., 1931 g.r., p. Voskhod, Zonal'nyj rajon. (in Rus.)

ACUiE LIK AltGPU, Kozhemyakina M.D., 1932 g.r. - Arhiv CUiE LIK AltGPU. [Archive of the Center for Oral History and Ethnography of the Laboratory of Historical Local History of the Altai State Pedagogical University]. F. IEE, 2002. Kozhemyakina M.D., 1932 g.r., p. Urozhajnyj, Zonal'nyj rajon. (in Rus.)

ACUiE LIK AltGPU, Kozhemyakin V.G., 1931 g.r. - Arhiv CUiE LIK AltGPU. [Archive of the Center for Oral History and Ethnography of the Laboratory of Historical Local History of the Altai State Pedagogical University]. F. IEE, 2002. Kozhemyakin V.G., 1931 g.r., p. Urozhajnyj, Zonal'nyj rajon. (in Rus.)

ACUiE LIK AltGPU, CHepurnyh T.A., 1926 g.r. - Arhiv CUiE LIK AltGPU. [Archive of the Center for Oral History and Ethnography of the Laboratory of Historical Local History of the Altai State Pedagogical University]. F. IEE, 2002. CHepurnyh T.A., 1926 g.r., p. Urozhajnyj, Zonal'nyj rajon. (in Rus.) 
ACUiE LIK AltGPU, Epihin I.P., 1927 g. r. - Arhiv CUiE LIK AltGPU. [Archive of the Center for Oral History and Ethnography of the Laboratory of Historical Local History of the Altai State Pedagogical University]. F. IEE, 2003. Epihin I.P., 1927 g. r., c. Pervomajskoe, Bijskij rajon. (in Rus.)

ACUiE LIK AltGPU, Kuzovleva O.E., 1919 g.r. - Arhiv CUiE LIK AltGPU. [Archive of the Center for Oral History and Ethnography of the Laboratory of Historical Local History of the Altai State Pedagogical University]. F. IEE, 2003. Kuzovleva O.E., 1919 g.r., c. Maloenisejskoe, Bijskij rajon. (in Rus.)

ACUiE LIK AltGPU, Novoskol'cev I.G., 1925 g.r. - Arhiv CUiE LIK AltGPU. [Archive of the Center for Oral History and Ethnography of the Laboratory of Historical Local History of the Altai State Pedagogical University]. F. IEE, 2003. Novoskol'cev I.G., 1925 g.r., c. Srostki, Bijskij rajon. (in Rus.)

ACUiE LIK AltGPU, Kovalik I. N., 1927 g.r. - Arhiv CUiE LIK AltGPU. [Archive of the Center for Oral History and Ethnography of the Laboratory of Historical Local History of the Altai State Pedagogical University]. F. IEE, 2004. Kovalik I. N., 1927 g.r., c. Krasnyj Partizan, CHaryshskij rajon. (in Rus.)

ACUiE LIK AltGPU, Hromenko N.V., 1947 g.r. - Arhiv CUiE LIK AltGPU. [Archive of the Center for Oral History and Ethnography of the Laboratory of Historical Local History of the Altai State Pedagogical University]. F. IEE, 2004. Hromenko N.V., 1947 g.r., c. Krasnyj Partizan, CHaryshskij rajon. (in Rus.)

ACUiE LIK AltGPU, Bozhanova V.A., 1938 g.r. - Arhiv CUiE LIK AltGPU. [Archive of the Center for Oral History and Ethnography of the Laboratory of Historical Local History of the Altai State Pedagogical University]. F. IEE, 2005. Bozhanova V.A., 1938 g.r., s. Novo-Obincevo, SHelabolihinskij rajon. (in Rus.)

ACUiE LIK AltGPU, Leonidova (Kinotop) A. V., 1937 g.r. - Arhiv CUiE LIK AltGPU. [Archive of the Center for Oral History and Ethnography of the Laboratory of Historical Local History of the Altai State Pedagogical University]. F. IEE, 2009. Leonidova (Kinotop) A. V., 1937 g.r., s. Pospeliha, Pospelihinskij rajon. (in Rus.)

ACUiE LIK AltGPU, Meuler (SHnajder) A. B., 1929 g.r. - Arhiv CUiE LIK AltGPU. [Archive of the Center for Oral History and Ethnography of the Laboratory of Historical Local History of the Altai State Pedagogical University]. F. IEE, 2012. Meuler (SHnajder) A. B., 1929 g.r., s. Zyat'kovo, Pankrushihinskij rajon. (in Rus.)

ACUiE LIK AltGPU, Bekker M. F., 1938 g.r. - Arhiv CUiE LIK AltGPU. [Archive of the Center for Oral History and Ethnography of the Laboratory of Historical Local History of the Altai State Pedagogical University]. F. IEE, 2012. Bekker M. F., 1938 g.r., s. Velizhanka, Pankrushihinskij rajon. (in Rus.)

ACUiE LIK AltGPU, Laputina T.K., 1921 g.r. - Arhiv CUiE LIK AltGPU. [Archive of the Center for Oral History and Ethnography of the Laboratory of Historical Local History of the Altai State Pedagogical University]. F. IEE, 2015. Laputina T.K., 1921 g.r., S. Blagoveshchenka, Blagoveshchenskij rajon. (in Rus.)

ACUiE LIK AltGPU, YAroshenko M.N., 1925 g.r. - Arhiv CUiE LIK AltGPU. [Archive of the Center for Oral History and Ethnography of the Laboratory of Historical Local History of the Altai State Pedagogical University]. F. IEE, 2015. YAroshenko M.N., 1925 g.r., s. Blagoveshchenka, Blagoveshchenskij rajon. (in Rus.)

ACUiE LIK AltGPU, Korotkih YU.K., 1932 g.r. - Arhiv CUiE LIK AltGPU. [Archive of the Center for Oral History and Ethnography of the Laboratory of Historical Local History of the Altai State Pedagogical University]. F. IEE, 2016. Korotkih YU.K., 1932 g.r., s. Ust'-CHaryshskaya Pristan', Ust'-Pristanskij rajon. (in Rus.)

ACUiE LIK AltGPU, Grineva T.A., 1931 g.r. - Arhiv CUiE LIK AltGPU. [Archive of the Center for Oral History and Ethnography of the Laboratory of Historical Local History of the Altai State Pedagogical University]. F. IEE, 2016. Grineva T.A., 1931 g.r., s. Ust'-CHaryshskaya Pristan', Ust'-Pristanskij rajon. (in Rus.)

ACUiE LIK AltGPU, Koshkarova N.S., 1926 g.r.- Arhiv CUiE LIK AltGPU. [Archive of the Center for Oral History and Ethnography of the Laboratory of Historical Local History of the Altai State Pedagogical University]. F. IEE, 2016. Koshkarova N.S., 1926 g.r., s. Ust'-CHaryshskaya Pristan', Ust'-Pristanskij rajon. (in Rus.)

ACUiE LIK AltGPU, SHemonaeva Z.S., 1925 g.r. - Arhiv CUiE LIK AltGPU. [Archive of the Center for Oral History and Ethnography of the Laboratory of Historical Local History of the Altai State Pedagogical University]. F. IEE, 2017. SHemonaeva Z.S., 1925 g.r., s. Krasnogorskoe, Krasnogorskij rajon. (in Rus.)

ACUiE LIK AltGPU, Koroleva V.V., 1931 g.r. - Arhiv CUiE LIK AltGPU. [Archive of the Center for Oral History and Ethnography of the Laboratory of Historical Local History of the Altai State 
Pedagogical University]. F. IEE, 2017. Koroleva V.V., 1931 g.r., s. Sosnovka, Krasnogorskij rajon. (in Rus.)

ACUiE LIK AltGPU, Vasyutin I.A., 1928 g.r. - Arhiv CUiE LIK AltGPU. [Archive of the Center for Oral History and Ethnography of the Laboratory of Historical Local History of the Altai State Pedagogical University]. F. IEE, 2017. Vasyutin Ivan Alekseevich, 1928 g.r., S. Ust'- Isha, Krasnogorskij rajon. (in Rus.)

ACUiE LIK AltGPU, Petrushina Z. A., 1937 g. r. - Arhiv CUiE LIK AltGPU. [Archive of the Center for Oral History and Ethnography of the Laboratory of Historical Local History of the Altai State Pedagogical University]. F. IEE, 2017. Petrushina Z. A., 1937 g. r., s. Ust'-Kazha, Krasnogorskij rajon. (in Rus.)

ACUiE LIK AltGPU, Leshchev A. F., 1926 g. r. - Arhiv CUiE LIK AltGPU. [Archive of the Center for Oral History and Ethnography of the Laboratory of Historical Local History of the Altai State Pedagogical University]. F. IEE, 2017. Leshchev A. F., 1926 g. r., s. Lebyazh'e, Krasnogorskij rajon. (in Rus.)

ACUiE LIK AltGPU, Popova M. I., 1930 g. r. - Arhiv CUiE LIK AltGPU. [Archive of the Center for Oral History and Ethnography of the Laboratory of Historical Local History of the Altai State Pedagogical University]. F. IEE, 2017. Popova M. I., 1930 g. r., s. Lebyazh'e, Krasnogorskij rajon. (in Rus.)

ACUiE LIK AltGPU, Dolgova A. S., 1923 g. r. - Arhiv CUiE LIK AltGPU. [Archive of the Center for Oral History and Ethnography of the Laboratory of Historical Local History of the Altai State Pedagogical University]. F. IEE, 2017. Dolgova A. S., 1923 g. r., s. Krasnogorskoe, Krasnogorskij rajon. (in Rus.)

ACUiE LIK AltGPU, Bykova R.K, 1941 g.r. - Arhiv CUiE LIK AltGPU. [Archive of the Center for Oral History and Ethnography of the Laboratory of Historical Local History of the Altai State Pedagogical University]. F. IEE, 2018. Bykova R.K, 1941 g.r., pos. Pobedim, Topchihinskij rajon. (in Rus.)

ACUiE LIK AltGPU, Ryabokonev I.V., 1934 g.r. - Arhiv CUiE LIK AltGPU. [Archive of the Center for Oral History and Ethnography of the Laboratory of Historical Local History of the Altai State Pedagogical University]. F. IEE, 2017. Ryabokonev Ivan Vasil'evich, 1934 g.r., s. Krasnogorskoe, Krasnogorskij rajon. (in Rus.)

Samcova, 2011 - Samcova E.V. 80 let so vremeni obrazovaniya sovhoza «CHistyun'skij» Topchihinskogo rajona Altajskogo kraya [80 years since the formation of the state farm "Chistyunsky" Topchihinsky district of the Altai Territory] // Altajskij kraj, 2012 g.: kalendar' znamenat. i pamyat. dat. Barnaul, 2011. S. 154-158. (in Rus.)

Pozdin, 2018 - Pozdin S.V. Repressirovannye armyane v Topchihinskom rajone [Repressed Armenians in Topchikhinsky district] // Topchihinskij rajon - kraevedcheskij sajt. [Elektronnyj resurs] / URL: http://top-kraeved.ru/category/istoriya/ (Data obrashcheniya 05.04.2019). (in Rus.)

Rodnaya storona, 2011 - Rodnaya storona: sbornik po istorii i kul'ture Topchihinskogo rajona [The home party: a collection on the history and culture of the Topchikha district]. Barnaul, 2011. S. 142-149. (in Rus.)

Rykov, 2016 - Rykov A. V. Ispol'zovanie myasa pavshih zhivotnyh v pitanii russkogo krest'yanstva Altajskogo kraya $v$ gody Velikoj Otechestvennoj vojny [The use of meat of dead animals in the nutrition of the Russian peasantry of the Altai Territory during the Great Patriotic War] // Tobol'sk nauchnyj - 2016 : Materialy XIII Vserossijskoj nauchno-prakticheskoj konferencii (c mezhdunarodnym uchastiem) (g. Tobol'sk, 10 -11 noyabrya 2016 g.). Tobol'sk, 2016. S. 272-275. (in Rus.)

Svidovskaya; Kovzel', 2018 - Svidovskaya A.S., Kovzel' A.V. Kukuruza v pitanii zhitelej Altajskogo kraya $\vee$ gody Velikoj Otechestvennoj vojny (po polevym materialam 2017 g.) [Corn in the diet of residents of the Altai Territory during the Great Patriotic War (according to field materials in 2017)] // CHastnoe i obshchestvennoe v povsednevnoj zhizni naseleniya Rossii: istoriya i sovremennost' (regional'nyj aspekt). Sbornik materialov mezhdunar. nauch. konf. / pod otv. red. S.V. Stepanov. Sankt-Peterburg, 2018. S. 159-165. (in Rus.)

Syshchenko, 2007 - Syshchenko A.G. Nemcy v Sibiri: Po dokumentam NKVD, MGB, MVD SSSR 1943-1956 gg.[Germans in Siberia: According to documents of the NKVD, MGB, Ministry of Internal Affairs of the USSR 1943-1956.]. Barnaul, 2007.623 s. (in Rus.)

Shcheglova, 2017 - Shcheglova T.K. Prinimayushchij altajskij socium i deportirovannye armyane v kontekste permanentnyh repressij i deportacij 1930-1940-h gg.: obrazy i kul'turnoe vzaimodejstvie [The host Altai society and the deported Armenians in the context of permanent repression and deportations of the 1930-1940s: images and cultural interaction] // Vestnik arheologii, antropologii i etnografii. 2017. № 2 (37) S. 137-145. (in Rus.)

Shcheglova, 2016 - Shcheglova T.K. Tradicii i novacii v obustrojstve zhiloj sredy russkogo naseleniya yuga Zapadnoj Sibiri v kontekste istoricheskogo razvitiya (1860-1980-e gg.) [Traditions and innovations in the arrangement of the living environment of the Russian population in the south of 
Western Siberia in the context of historical development (1860-1980s)] // Tradicionnaya kul'tura. 2016. № 1. S. 164-174. (in Rus.)

Shcheglova, 2015 - Shcheglova T.K. Etnografiya russkogo krest'yanstva yuga Zapadnoj Sibiri v XX stoletii: Kul'tura zhizneobespecheniya v gody Velikoj Otechestvennoj vojny: Nauchnye i metodicheskie materialy [Ethnography of the Russian peasantry in the south of Western Siberia in the 20th century: Culture of sustenance during the years of the Great Patriotic War: Scientific and methodological materials.]. Barnaul: Azbuka, 2015. 132 s. (in Rus.)

Shcheglova, 2018 - Shcheglova T.K. Kul'tura i byt russkogo sel'skogo naseleniya yuga Zapadnoj Sibiri v 1930-1950-h gg.: zhilishche, pishcha, odezhda, semejnye i trudovye tradicii : monografiya [Culture and life of the Russian rural population of the south of Western Siberia in the 19301950s: housing, food, clothing, family and work traditions: a monograph.]. Barnaul : AltGPU, 2018. 508 s. (in Rus.)

Shcheglova, 2008 - Shcheglova T.K.. Derevnya i krest'yanstvo Altajskogo kraya v XX veke. Ustnaya istoriya : monografiya.[The village and the peasantry of the Altai Territory in the XX century. Oral history: monograph.]. Barnaul : BGPU, 2008. 527 s. (in Rus.)

Shcheglova, 2011 - Shcheglova T.K. Ustnaya istoriya : uchebnoe posobie dlya studentov vuzov. [Oral history: a textbook for university students.]. Barnaul : AltGPA, 2011. 363 s. (in Rus.) 